\title{
Profiles of Active Transportation among Children and Adolescents in the Global Matrix 3.0 Initiative: A 49-Country Comparison
}

\author{
Silvia A. González ${ }^{1,2, *}$ (), Salomé Aubert ${ }^{1}$, Joel D. Barnes ${ }^{1}{ }^{\circledR}$, Richard Larouche ${ }^{1,3}$ and \\ Mark S. Tremblay ${ }^{1,2}$ \\ 1 Healthy Active Living and Obesity Research Group, Children's Hospital of Eastern Ontario Research \\ Institute, Ottawa, ON K1H 8L1, Canada; saubert@cheo.on.ca (S.A.); j@barnzilla.ca (J.D.B.); \\ richard.larouche@uleth.ca (R.L.); mtremblay@cheo.on.ca (M.S.T.) \\ 2 School of Epidemiology and Public Health, Faculty of Medicine, University of Ottawa, Ottawa, \\ ON K1G 5Z3, Canada \\ 3 Faculty of Health Sciences, University of Lethbridge, 4401 University Drive, Lethbridge, \\ AB T1K 3M4, Canada \\ * Correspondence: sa.gonzalez68@uniandes.edu.co; Tel.: +1-613-9818332
}

Received: 27 June 2020; Accepted: 14 August 2020; Published: 18 August 2020

\begin{abstract}
This article aims to compare the prevalence of active transportation among children and adolescents from 49 countries at different levels of development. The data was extracted from the Report Cards on Physical Activity for Children and Youth from the 49 countries that participated in the Global Matrix 3.0 initiative. Descriptive statistics and a latent profile analysis with active transportation, Human Development Index and Gini index as latent variables were conducted. The global average grade was a " $\mathrm{C}$ ", indicating that countries are succeeding with about half of children and youth $(47-53 \%)$. There is wide variability in the prevalence and in the definition of active transportation globally. Three different profiles of countries were identified based on active transportation grades, Human Development Index (HDI) and income inequalities. The first profile grouped very high HDI countries with low prevalence of active transport and low inequalities. The second profile grouped low and middle HDI countries with high prevalence of active transportation and higher inequalities. And the third profile was characterized by the relatively high prevalence of active transportation and more variability in the socioeconomic variables. Promising policies from countries under each profile were identified. A unified definition of active transportation and contextualized methods for its assessment are needed to advance in surveillance and practice.
\end{abstract}

Keywords: cycling; walking; health promotion; policy; latent profile analysis; surveillance

\section{Introduction}

The world is experiencing a crisis of physical inactivity with almost $80 \%$ of adolescents not achieving the recommended $60 \mathrm{~min}$ of daily moderate to vigorous physical activity for health [1]. In this context, transportation, as a daily necessity to move from one place to another, represents a promising domain to promote the accumulation of physical activity in children and adolescents in a convenient and habitual manner [2]. Specifically, active transportation to/from school is an opportunity to integrate physical activity into children's and adolescent's routines [3].

Active transportation comprises non-motorized travel modes like walking, cycling or riding a scooter, among others [4]. The use of these active modes leads not only to health benefits such as greater levels of cardiorespiratory fitness [3,5] and better cardiometabolic health indicators [6] among children who actively commute, but also to other co-benefits, such as better mental health 
outcomes [7,8], greater interaction with their environment [9], and reduced transportation-related emissions and pollution [10]. Despite these benefits, current evidence suggests that this behaviour is declining in many countries [11].

In the same way that physical inactivity prevalence varies widely across countries [1], a wide variation in active transportation could be expected. These variations represent an opportunity to identify those countries that are succeeding with active transportation behaviours, and those that require action to increase active transportation or prevent a decline in this behaviour. However, to the best of our knowledge, the few international comparisons of data on active transportation among children and adolescents include mostly small groups of countries or the availability of national representative data is limited [11-13]. Therefore, the Global Matrix 3.0 of Report Card grades on physical activity among children and youth provides an opportunity to describe and examine the global situation of active transportation. For the first time, 49 countries from all continents reported data on an active transportation indicator at the national level [14]. The aims of this study were to compare the prevalence of active transportation among children and adolescents from 49 countries participating in the Global Matrix 3.0, to identify a set of profiles to group the countries according to their prevalence of active transport and sociodemographic variables, and to discuss policies and practices implemented across different countries to increase active transportation.

\section{Materials and Methods}

The Global Matrix 3.0 was an international initiative released in 2018 and led by the Active Healthy Kids Global Alliance (AHKGA). This project brought together 513 researchers and physical activity leaders from 49 countries around the world [15]. All the participating countries followed a harmonized process to develop Report Cards on the physical activity of children and youth. A detailed description of the countries' involvement and the process to develop the Report Cards has been published elsewhere and is briefly described here [14].

In each country, National Report Card Committees gathered the best and most recent national surveillance data available up to 2018 to inform and grade ten specific indicators related to physical activity among children and adolescents: Overall Physical Activity, Organized Sport and Physical Activity, Active Play, Active Transportation, Sedentary Behaviours, Physical Fitness, Family and Peers, School, Community and Environment, and Government [14]. The analyses presented in this paper are focused on the Active Transportation indicator.

According to the benchmarks proposed by AHKGA to harmonize and guide the development of the Report Cards, the Active Transportation indicator was described as the "percentage of children and youth who use active transportation to get to and from places (e.g., school, park, mall, friend's house)" [14]. Report card leaders were instructed to inform this indicator by the best, preferably nationally representative, data available for children and adolescents between five and 17 years, and a grade was assigned according to the prevalence following a common rubric established by the AHKGA (Table 1).

The prevalence of active transportation reported by each country and the related details presented in each Report Card, including policies, practices, strategies to improve the grade and research gaps, were extracted from the Report Cards and from related publications in English, Spanish or French, including brief reports, posters and peer-reviewed articles. These publications were reviewed, and relevant information was summarized by two of the authors of this manuscript. Based on the grades provided, numerical equivalents were assigned (Table 1), and average estimates of the grades for active transportation were calculated at the global level and by groups of countries according to their level of development determined by the Human Development Index (HDI). The HDI is a composite index created by the United Nations Development Programme (New York, NY, USA) to rank countries based on key dimensions of human development such as education, life expectancy and gross national income per capita [16]. HDI ranges from 0 to 1 and for the present analysis we used the continuous index and a categorical variable that classified countries in three categories: low and 
medium (HDI $<0.70)$, high (HDI $\geq 0.70$ to $<0.80$ ) and very high (HDI $\geq 0.80)$ [16]. It was included as a variable of interest in this analysis based on the variability in active transportation observed across HDI clusters in previous analysis of the Global Matrix [14]. Also, the Gini index for each country was retrieved from the World Bank estimates. The Gini index provides a measure of inequality in income distribution. It ranges from 0 (perfect equality) to 100 (perfect inequality) [17]. The Gini index was included in this analysis considering previous international evidence that has shown that income inequality is a relevant variable related to physical activity levels and taking into account the importance of socioeconomic inequalities in transport as an essential activity for economic and social development $[18,19]$.

Table 1. Global Matrix 3.0 grading rubric.

\begin{tabular}{clc}
\hline Grade & \multicolumn{1}{c}{ Interpretation $^{\text {a }}$} & Numerical Equivalents ${ }^{\mathbf{b}}$ \\
\hline A+ & $94-100 \%$ & 15 \\
\hline A & We are succeeding with a large majority of children and youth $(87-93 \%)$ & 14 \\
\hline A- & $80-86 \%$ & 13 \\
\hline B+ & $74-79 \%$ & 12 \\
\hline B & We are succeeding with well over half of children and youth $(67-73 \%)$ & 11 \\
\hline B- & $60-66 \%$ & 10 \\
\hline C+ & $54-59 \%$ & 9 \\
\hline C & We are succeeding with about half of children and youth $(47-53 \%)$ & 8 \\
\hline C- & $40-46 \%$ & 7 \\
\hline D+ & $34-39 \%$ & 6 \\
\hline D & We are succeeding with less than half but some children and youth $(27-33 \%)$ & 5 \\
\hline D- & $20-26 \%$ & 4 \\
\hline F & We are succeeding with very few children and youth $(<20 \%)$ & 2 \\
\hline INC ${ }^{\mathbf{c}}$ & Incomplete-insufficient or inadequate information to assign a grade & \\
\hline $\begin{array}{l}\text { a For this article, the interpretation corresponds to the percentage of children and youth who use active transportation } \\
\text { to get to and from places (e.g., school, park, mall, friend's house). }{ }^{b} \text { Letter grades were converted to numerical }\end{array}$
\end{tabular}

A latent profile analysis (LPA) was conducted to identify groups or profiles of countries based on the numerical grades for active transportation and the two sociodemographic variables at the country level, the HDI and the Gini index. LPA is a probability-based statistical procedure that allows to identify classes or profiles that group observations sharing similar patterns of the variables of interest [20]. The analysis was performed to look for the best model solution for one to five possible profiles. Models were compared to choose the solution with the best fit based on the Akaike information criterion (AIC), sample-adjusted Bayesian information criterion (SABIC) and the bootstrapped likelihood ratio test (BLRT) as indicators of model fit. All statistical analyses were performed using SAS 9.4 (SAS Institute, Cary, NC, USA) and R (version 3.4.1, The R Foundation for Statistical Computing, Vienna, Austria). The tidyLPA package [21] was used for the LPA.

\section{Results}

A total of 47 countries (96\%) in the Global Matrix 3.0 had sufficient evidence (determined by each country's National Report Card Committee) on active transportation to assign a grade. The grades ranged from "A-" in Japan, Nepal and Zimbabwe to " $\mathrm{F}$ " in Chile (Table 2). The global average for active transportation was " $\mathrm{C}$ ". The average grade by HDI was " $\mathrm{C}+$ " for low to medium HDI countries, "C" for high HDI countries and " $\mathrm{C}-$ " for very high HDI countries, as previously reported by Aubert et al. [14]. The HDI of the included countries varied from 0.448 in Ethiopia to 0.985 in Jersey. According to the Gini index, the country with the most unequal distribution of income was South Africa with a Gini index of 63, while Slovenia had the lowest inequality score, with a Gini of 25.4 (Table 2). 
Table 2. Active transportation grades and sociodemographic variables of the 49 countries participating in the Global Matrix 3.0.

\begin{tabular}{|c|c|c|c|c|c|}
\hline Country & $\begin{array}{l}\text { Active Transport } \\
\text { Grade }\end{array}$ & $\begin{array}{l}\text { Active Transport } \\
\text { Numerical Grade }\end{array}$ & $\begin{array}{l}\text { Human Development } \\
\text { Index (HDI) }^{\mathbf{a}}\end{array}$ & $\begin{array}{c}\text { HDI } \\
\text { Classification }\end{array}$ & $\begin{array}{c}\text { Gini } \\
\text { Index }^{b}\end{array}$ \\
\hline Australia & $\mathrm{D}+$ & 6 & 0.939 & Very high & 34.7 \\
\hline Bangladesh & $\mathrm{C}-$ & 7 & 0.579 & Low to medium & 32.4 \\
\hline Belgium (Flanders) & $\mathrm{C}+$ & 9 & 0.896 & Very high & 27.7 \\
\hline Botswana & $\mathrm{C}$ & 8 & 0.698 & Low to medium & 60.5 \\
\hline Brazil & $\mathrm{C}$ & 8 & 0.754 & High & 51.3 \\
\hline Bulgaria & B- & 10 & 0.794 & High & 37.4 \\
\hline Canada & $\mathrm{D}-$ & 4 & 0.920 & Very high & 34.0 \\
\hline Chile & $\mathrm{F}$ & 2 & 0.847 & Very high & 47.7 \\
\hline China & $\mathrm{C}+$ & 9 & 0.738 & High & 42.2 \\
\hline Colombia & B & 11 & 0.727 & High & 50.8 \\
\hline Czech Republic & $\mathrm{C}+$ & 9 & 0.878 & Very high & 25.9 \\
\hline Denmark & $\mathrm{B}+$ & 12 & 0.925 & Very high & 28.2 \\
\hline Ecuador & $\mathrm{C}-$ & 7 & 0.739 & High & 45.0 \\
\hline England & $\mathrm{C}-$ & 7 & 0.909 & Very high & 33.2 \\
\hline Estonia & $\mathrm{D}$ & 5 & 0.865 & Very high & 32.7 \\
\hline Ethiopia & $\mathrm{C}$ & 8 & 0.448 & Low to medium & 39.1 \\
\hline Finland & $\mathrm{B}+$ & 12 & 0.895 & Very high & 27.1 \\
\hline France & $\mathrm{C}-$ & 7 & 0.897 & Very high & 32.7 \\
\hline Germany & $\mathrm{C}-$ & 7 & 0.926 & Very high & 31.7 \\
\hline Ghana & $\mathrm{C}+$ & 9 & 0.579 & Low to medium & 42.4 \\
\hline Guernsey Channel Islands & $\mathrm{D}$ & 5 & 0.975 & Very high & 40.0 \\
\hline Hong Kong & $\mathrm{B}+$ & 12 & 0.917 & Very high & N/A \\
\hline India & B- & 10 & 0.624 & Low to medium & 35.1 \\
\hline Japan & A- & 13 & 0.903 & Very high & 32.1 \\
\hline Jersey & $\mathrm{D}+$ & 6 & 0.985 & Very high & 41.0 \\
\hline Lebanon & $\mathrm{D}$ & 5 & 0.763 & High & 31.8 \\
\hline Lithuania & $\mathrm{C}-$ & 7 & 0.848 & Very high & 37.4 \\
\hline Mexico & $\mathrm{C}+$ & 9 & 0.762 & High & 43.4 \\
\hline Nepal & A- & 13 & 0.558 & Low to medium & 32.8 \\
\hline Netherlands & $\mathrm{B}-$ & 10 & 0.924 & Very high & 29.3 \\
\hline New Zealand & $\mathrm{C}-$ & 7 & 0.915 & Very high & N/A \\
\hline Nigeria & $\mathrm{B}$ & 11 & 0.527 & Low to medium & 43.0 \\
\hline Poland & $\mathrm{C}$ & 8 & 0.855 & Very high & 31.8 \\
\hline Portugal & $\mathrm{C}-$ & 7 & 0.843 & Very high & 35.5 \\
\hline Qatar & N/A & N/A & 0.856 & Very high & N/A \\
\hline Scotland & $\mathrm{C}$ & 8 & 0.909 & Very high & 33.2 \\
\hline Slovenia & $\mathrm{C}$ & 8 & 0.890 & Very high & 25.4 \\
\hline South Africa & $\mathrm{C}$ & 8 & 0.666 & Low to medium & 63.0 \\
\hline South Korea & $\mathrm{B}+$ & 12 & 0.901 & Very high & 31.6 \\
\hline Spain & $\mathrm{B}-$ & 10 & 0.884 & Very high & 36.2 \\
\hline Sweden & $\mathrm{C}$ & 8 & 0.913 & Very high & 29.2 \\
\hline Taiwan & $\mathrm{C}-$ & 7 & 0.885 & Very high & 33.6 \\
\hline Thailand & $\mathrm{C}$ & 8 & 0.740 & High & 37.8 \\
\hline United Arab Emirates & INC & N/A & 0.840 & Very high & N/A \\
\hline United States & D- & 4 & 0.920 & Very high & 41.5 \\
\hline
\end{tabular}


Table 2. Cont.

\begin{tabular}{|c|c|c|c|c|c|}
\hline Country & $\begin{array}{c}\text { Active Transport } \\
\text { Grade }\end{array}$ & $\begin{array}{l}\text { Active Transport } \\
\text { Numerical Grade }\end{array}$ & $\begin{array}{l}\text { Human Development } \\
\text { Index (HDI) }^{a}\end{array}$ & $\begin{array}{c}\text { HDI } \\
\text { Classification }\end{array}$ & $\underset{\text { Index }^{b}}{\text { Gini }}$ \\
\hline Uruguay & $\mathrm{C}$ & 8 & 0.795 & High & 39.7 \\
\hline Wales & $\mathrm{D}+$ & 6 & 0.909 & Very high & 33.2 \\
\hline Zimbabwe & $A-$ & 13 & 0.516 & Low to medium & 43.2 \\
\hline $\begin{array}{l}\text { Low to medium HDI } \\
\text { countries }\end{array}$ & $\mathrm{C}+$ & 9.67 & NA & NA & NA \\
\hline High HDI countries & $\mathrm{C}$ & 8.5 & NA & NA & NA \\
\hline Very high HDI counties & $\mathrm{C}-$ & 7.78 & NA & NA & NA \\
\hline
\end{tabular}

${ }^{a}$ Data at the national level from the United Nations Development Programme [16]. ${ }^{\mathrm{b}}$ Data at the national level from the World Bank [17]. Abbreviations: HDI, Human Development Index; INC, Incomplete, N/A, Not available; NA, Not Applicable.

Table 3 presents the prevalence and rationales behind the grades for each country, as well as the sources and characteristics of the information reported. Active transportation among children and adolescents varied between $15 \%$ in Chile and $86 \%$ in Japan and Nepal. Among the countries that assigned a grade for active transportation, $83 \%(n=39)$ did not provide details of the prevalence stratified by sex. In the majority (62\%) of countries that reported data by sex, the prevalence of active transportation was slightly higher for males. More than half of the countries $(65 \%)$ reported data for both children and adolescents, however, the age groups included varied from one country to another. Most countries (87\%) only included data on school trips, and only two countries (Ecuador and the United States) clearly reported active transportation to other destinations. Regarding the direction of the trips, about half of the countries ( $49 \%$ ) reported active transportation to and from school or other destinations. In more than half of the countries (65\%), the frequency of active transportation reported was not clear. The most common frequencies reported were "daily" $(n=3)$, "typically" or "usually" ( $n=3)$ and "on a regular basis" $(n=2)$. Regarding the source of information, $64 \%(n=30)$ of the countries used data from surveys and studies with national representativeness, $8.5 \%(n=4)$ used local studies, and 19\% $(n=9)$ used both local and national studies. International surveys such as the Global School-Based Student Health Survey (GSHS) [22] and the Health Behaviour of School-aged Children (HBSC) [23] were among the sources of information in seven countries.

The best LPA model grouped the Global Matrix 3.0 countries into three profiles according to the grades for active transportation, the HDI and the Gini index. The three-profile model had the best fit statistics according to the criteria proposed by Nylund et al. for model selection [24]. The preferred model showed the lowest values for the AIC (359.8), SABIC (331.1) and the BLRT (24.8), and a significant $p$ value for the BLRT $(p=0.041)$. Table 4 shows the descriptive statistics for the latent variables among the three profiles identified. In profile $1(n=25) 72 \%$ of the countries had active transportation grades below " $\mathrm{C}$ ", $96 \%$ of the countries had a very high HDI, and $72 \%$ had relatively low Gini indices (below 40). In profile $2(n=7), 85 \%$ of the countries had active transportation grades equal to or greater than " $\mathrm{C}$ ", all of them had a low to medium HDI and $43 \%$ had Gini indices above 40 . In profile $3(n=17)$, $94 \%$ of the countries had active transportation grades equal to or greater than " $\mathrm{C}$ ", $53 \%$ had a high HDI and $35 \%$ had a very high HDI, and $47 \%$ had Gini indices above 40 . For countries with missing values in any of the variables of interest, the LPA assigned a profile based on the values available for the remaining variables. Figure 1 presents a plot of the scaled data for the three profiles. 
Table 3. Rationale for grades and information reported on active transportation by 49 countries involved in the Global Matrix 3.0.

\begin{tabular}{|c|c|c|c|c|c|c|c|c|}
\hline Grade & Country & Rationale & Gender & Age & $\begin{array}{c}\text { Destination } \\
\text { and Direction }\end{array}$ & Frequency & Source of Information and Year & Profile \\
\hline A- & Japan & $\begin{array}{l}86 \% \text { of students used active transportation to } \\
\text { school from home. }\end{array}$ & Not reported & $6-17$ years & To school & $\begin{array}{l}\text { On a regular } \\
\text { basis }\end{array}$ & $\begin{array}{l}\text { The National Sports-Life Survey of } \\
\text { Young People (SSF), } 2015 \text { [25] }\end{array}$ & 3 \\
\hline A- & Nepal & $\begin{array}{l}86 \% \text { of children and youth of } 15-20 \text { years used } \\
\text { active transportation to get to and from places. }\end{array}$ & Not reported & $15-20$ years & Not specified & Not clear & $\begin{array}{l}\text { Physical Activity Level and } \\
\text { Associated Factors Among Higher } \\
\text { Secondary School Students in } \\
\text { Banke, Nepal: A Cross-Sectional } \\
\text { Study, } 2013 \text { [26] }\end{array}$ & 2 \\
\hline A- & Zimbabwe & $\begin{array}{l}\text { Over } 80 \% \text { of children and adolescents used active } \\
\text { transport to and from school, with variation } \\
\text { between provinces as well as between rural and } \\
\text { urban areas. }\end{array}$ & $\begin{array}{l}82 \% \text { of girls and } 79 \% \text { of } \\
\text { boys engaged in active } \\
\text { transport to and from } \\
\text { school }\end{array}$ & $8-16$ years & $\begin{array}{l}\text { To and from } \\
\text { School }\end{array}$ & Not clear & $\begin{array}{l}\text { The Zimbabwe Baseline [27] and } \\
\text { Global school-based } \\
\text { health survey (GSHS) Zimbabwe } \\
2003 \text { [28] }\end{array}$ & 2 \\
\hline $\mathrm{B}+$ & Denmark & $\begin{array}{l}78 \% \text { of children and adolescents reported cycling, } \\
\text { walking, or using children's scooters as transport } \\
\text { (e.g., to school) at least two times per week. }\end{array}$ & Not reported & $7-15$ years & To school & $\begin{array}{l}\text { At least two } \\
\text { times per week }\end{array}$ & $\begin{array}{l}\text { Danish Sports Habits Study } \\
2016 \text { [29] }\end{array}$ & 3 \\
\hline $\mathrm{B}+$ & Finland & $\begin{array}{l}77 \% \text { of children and adolescents actively commuted } \\
\text { to school, on foot or by bike. }\end{array}$ & $\begin{array}{l}9 \text { years old } 79 \% \text { of boys, } \\
81 \% \text { of girls } 11 \text { years old } \\
85 \% \text { of boys, } 81 \% \text { of girls } \\
13 \text { years old } 80 \% \text { of boys, } \\
77 \% \text { of girls } 15 \text { years old } \\
59 \% \text { of boys, } 63 \% \text { of girls }\end{array}$ & $9-15$ years & To school & Not clear & $\begin{array}{l}\text { National Physical Activity } \\
\text { Behaviour Study for Children and } \\
\text { Adolescents } 2016 \text { (LITTU) [30] }\end{array}$ & 3 \\
\hline B+ & Hong Kong & $\begin{array}{l}80 \% \text { of the adolescent males and } 77 \% \text { of the } \\
\text { adolescent females actively travelled to school at } \\
\text { least once per week. } \\
52 \% \text { of primary school children used active travel } \\
\text { to/from school at least } 5 \text { times per week. }\end{array}$ & $\begin{array}{l}80 \% \text { adolescent males and } \\
77 \% \text { adolescent females }\end{array}$ & $\begin{array}{l}\text { Primary and } \\
\text { secondary }\end{array}$ & $\begin{array}{l}\text { To and from } \\
\text { school }\end{array}$ & $\begin{array}{l}\text { At least } 5 \text { times } \\
\text { per week and at } \\
\text { least once per } \\
\text { week }\end{array}$ & $\begin{array}{l}\text { Understanding Children's Activity } \\
\text { and Nutrition (UCAN) study, } \\
\text { 2011-2012 [31] }\end{array}$ & 3 \\
\hline $\mathrm{B}+$ & South Korea & $\begin{array}{l}79.4 \% \text { of children and adolescents reported walking } \\
\text { or cycling to/from places, with an average duration } \\
\text { of } 39 \text { min per day. }\end{array}$ & $\begin{array}{l}84.3 \% \text { of boys and } 73.8 \% \text { of } \\
\text { girls took active modes of } \\
\text { transport }\end{array}$ & $12-17$ years & Not specified & Not clear & $\begin{array}{l}\text { Korea National Health and } \\
\text { Nutrition Examination Survey, } \\
2016 \text { [32] }\end{array}$ & 3 \\
\hline B & Colombia & $\begin{array}{l}71.7 \% \text { of children and adolescents in Colombia } \\
\text { reported walking or biking as their main mode of } \\
\text { transport to or from school in the previous week. }\end{array}$ & Not reported & $6-17$ years & $\begin{array}{l}\text { To and from } \\
\text { school }\end{array}$ & $\begin{array}{l}\text { Main mode } \\
\text { during the last } 7 \\
\text { days }\end{array}$ & $\begin{array}{l}\text { National Survey of Nutrition } \\
\text { (ENSIN) } 2015 \text { [33] }\end{array}$ & 3 \\
\hline B & Nigeria & $\begin{array}{l}\text { The majority }(61 \% \text { to } 80 \%) \text { of Nigerian children and } \\
\text { adolescents engage in some form of active } \\
\text { transportation, mostly walking to and from school. }\end{array}$ & Not reported & $5-13$ years & $\begin{array}{l}\text { To and } \\
\text { from school }\end{array}$ & Not clear & $\begin{array}{l}2 \text { different studies on rural and } \\
\text { urban populations in Nigeria, } \\
\text { conducted in } 2011 \text { [34] and } \\
2013 \text { [35] }\end{array}$ & 2 \\
\hline
\end{tabular}


Table 3. Cont

\begin{tabular}{|c|c|c|c|c|c|c|c|c|}
\hline Grade & Country & Rationale & Gender & Age & $\begin{array}{c}\text { Destination } \\
\text { and Direction }\end{array}$ & Frequency & Source of Information and Year & Profile \\
\hline B- & Bulgaria & $\begin{array}{l}64 \% \text { of children and youth reported walking, } \\
\text { biking, or skating, etc. to go to school and back. }\end{array}$ & Not reported & Not specified & $\begin{array}{l}\text { To and from } \\
\text { school }\end{array}$ & Not clear & $\begin{array}{l}\text { Bulgarian Active Kids survey, } \\
2016[36]\end{array}$ & 3 \\
\hline B- & India & $\begin{array}{l}\text { Approximately } 65 \% \text { of children/adolescents } \\
\text { (weighted average) reported walking or cycling to } \\
\text { school on a regular basis. }\end{array}$ & Not reported & $5-17$ years & To school & $\begin{array}{l}\text { On a regular } \\
\text { basis }\end{array}$ & $\begin{array}{l}7 \text { different studies at the national } \\
\text { and local level conducted between } \\
2005 \text { and } 2018[12,13,37-41]\end{array}$ & 2 \\
\hline B- & Netherlands & $\begin{array}{l}90 \% \text { of the adolescents commute actively to school. } \\
36 \% \text { of the children commute actively to school }\end{array}$ & Not reported & Not specified & To school & $\begin{array}{l}\text { At least three } \\
\text { days per week }\end{array}$ & $\begin{array}{l}\text { Lifestyle monitor National Survey, } \\
2017 \text { [42] }\end{array}$ & 1 \\
\hline B- & Spain & $\begin{array}{l}55 \% \text { and } 56.9 \% \text { of children between } 6 \text { and } 9 \text { years } \\
\text { old walked to and from school, respectively. } \\
\text { In Catalonia, } 61.3 \% \text { of children between } 3 \text { to } 14 \\
\text { years old walked to and from school. }\end{array}$ & Not reported & 3-14 years & $\begin{array}{l}\text { To and from } \\
\text { school }\end{array}$ & Not clear & $\begin{array}{l}\text { Food, Physical Activity, Child } \\
\text { developmentand Obesity study } \\
\text { (ALADINO) } 2011 \text { [43], and the } \\
\text { Catalan Health Survey (ESCA) } \\
2016 \text { [44] }\end{array}$ & 3 \\
\hline B- & Venezuela & $\begin{array}{l}63 \% \text { of adolescents might walk at least } 10 \mathrm{~min} \text { to } \\
\text { move from one place to another. }\end{array}$ & Not reported & Not specified & Not specified & Not clear & $\begin{array}{l}\text { Venezuelan Study of Nutrition and } \\
\text { Health [45] }\end{array}$ & 3 \\
\hline $\mathrm{C}+$ & $\begin{array}{l}\text { Belgium } \\
\text { (Flanders) }\end{array}$ & $\begin{array}{l}55.5 \% \text { of parents of 6-to } 9 \text {-year old children reported } \\
\text { that their child uses active transportation, and } 58.9 \% \\
\text { of } 10-\text { to } 17 \text {-year-olds adolescents reported to } \\
\text { mainly use active transportation to travel to school. }\end{array}$ & Not reported & $\begin{array}{l}6 \text { to } 9 \text { and } 10 \\
\quad \text { to } 17\end{array}$ & To school & Not clear & $\begin{array}{l}\text { Belgian National Food } \\
\text { Consumption Survey } 2014 \text { [46] }\end{array}$ & 1 \\
\hline $\mathrm{C}+$ & China & $\begin{array}{l}56.3 \% \text { of Chinese children (aged 6-18 years) } \\
\text { reported going to and from school by walk } \\
\text { or bicycle. }\end{array}$ & Not reported & 9 to 17 years & $\begin{array}{l}\text { To and from } \\
\text { school }\end{array}$ & Daily & $\begin{array}{l}\text { Physical Activity and Fitness in } \\
\text { China-The Youth Study } \\
\text { (PAFCTYS), 2016 [47] }\end{array}$ & 3 \\
\hline $\mathrm{C}+$ & $\begin{array}{l}\text { Czech } \\
\text { Republic }\end{array}$ & $\begin{array}{l}\text { On average, } 57 \% \text { (weighted mean: } 59 \% \text { ) of children } \\
\text { and adolescents reported using active transport to } \\
\text { get to and from school. }\end{array}$ & Not reported & $9-17$ years & $\begin{array}{l}\text { To and from } \\
\text { school }\end{array}$ & Not clear & $\begin{array}{l}\text { Health Behaviour in School-aged } \\
\text { Children Study (HBSC)2006, 2010, } \\
\text { and } 2014 \text { [48] and International } \\
\text { Physical Activity and Environment } \\
\text { Network Study (IPEN), } \\
\text { 2013-2015 [49] }\end{array}$ & 1 \\
\hline $\mathrm{C}+$ & Ghana & $\begin{array}{l}\text { About } 54 \% \text { of children and youth especially those } \\
\text { in the rural areas walk to school and back home } \\
\text { covering about } 2 \mathrm{~km} \text {. }\end{array}$ & Not reported & Not specified & $\begin{array}{l}\text { To and from } \\
\text { school }\end{array}$ & Not clear & Not specified & 2 \\
\hline $\mathrm{C}+$ & Mexico & $\begin{array}{l}54.8 \% \text { of children } 3 \text { years and older walked to } \\
\text { school and } 1.5 \% \text { rode bicycles. } 69 \% \text { of } \\
10-14 \text {-year-olds walked or rode a bicycle to school. }\end{array}$ & Not reported & $\begin{array}{l}3 \text { years and } \\
\text { older }\end{array}$ & To school & Not clear & $\begin{array}{l}\text { Intercensal Survey of the National } \\
\text { Institute of Statistics and } \\
\text { Geography (INEGI), 2015 [50] and } \\
\text { the National Health and Nutrition } \\
\text { Survey } 2016 \text { (ENSANUT) [51] }\end{array}$ & 3 \\
\hline
\end{tabular}


Table 3. Cont

\begin{tabular}{|c|c|c|c|c|c|c|c|c|}
\hline Grade & Country & Rationale & Gender & Age & $\begin{array}{l}\text { Destination } \\
\text { and Direction }\end{array}$ & Frequency & Source of Information and Year & Profile \\
\hline C & Botswana & $\begin{array}{l}49 \% \text { of } 13-15 \text {-year-olds walked or rode a bike to and } \\
\text { from school at least one day during the past } 7 \text { days. }\end{array}$ & Not reported & $13-15$ & $\begin{array}{l}\text { To and from } \\
\text { school }\end{array}$ & $\begin{array}{l}\text { At least one of } \\
\text { the last } 7 \text { days }\end{array}$ & $\begin{array}{l}2005 \text { Botswana School-based } \\
\text { Student Health Survey (GSHS) [13] }\end{array}$ & 3 \\
\hline C & Brazil & $\begin{array}{l}55.0 \% \text { of children and youth in Brazil used active } \\
\text { transportation to get to and from school. }\end{array}$ & Not reported & 6 to 21 & $\begin{array}{l}\text { To and from } \\
\text { school }\end{array}$ & Not clear & $\begin{array}{l}18 \text { different national and regional } \\
\text { studies conducted between } 2008 \\
\text { and } 2017 \text { [52] }\end{array}$ & 3 \\
\hline C & Ethiopia & $\begin{array}{l}\text { Approximately } 48 \% \text { of children and youth ( } 31 \% \text { in } \\
\text { urban and } 65 \% \text { rural) walked to and from school. }\end{array}$ & Not reported & Not specified & $\begin{array}{l}\text { To and from } \\
\text { school }\end{array}$ & Not clear & Experts' opinion & 2 \\
\hline C & Poland & $\begin{array}{l}\text { 47.4\% of } 10 \text { - to } 17 \text {-year-olds reported walking to } \\
\text { school and } 52.3 \% \text { walking from school. } 5.5 \% \text { and } \\
5.2 \% \text { travel to and from school by bicycle, } \\
\text { respectively. } \\
41 \% \text { and } 5 \% \text { of lower-secondary students walk and } \\
\text { cycle to school, respectively. While } 36 \% \text { and } 3 \% \text { of } \\
\text { upper-secondary school students walk and cycle to } \\
\text { school, respectively. }\end{array}$ & Not reported & $10-19$ years & $\begin{array}{l}\text { To and from } \\
\text { school }\end{array}$ & Not clear & $\begin{array}{l}\text { Study of Physical Activity of } \\
\text { School Children Aged 9-17 by the } \\
\text { Institute of Mother and Child, } \\
2013 \text { [53] and the All-Poland } \\
\text { survey of physical activity and } \\
\text { sedentary lifestyles for middle } \\
\text { school, high school and university } \\
\text { students, } 2011 \text { [54] }\end{array}$ & 1 \\
\hline C & Scotland & $\begin{array}{l}51 \% \text { and } 52 \% \text { of school age children and } \\
\text { adolescents, respectively, actively commuted to } \\
\text { school (walking, cycling, skating or using scooter). }\end{array}$ & Not reported & $4-18$ years & To school & Not clear & $\begin{array}{l}\text { Hands up Scotland Survey (HUS) } \\
2016 \text { [55], Transport and Travel in } \\
\text { Scotland (TATiS) } 2016 \text { [56] }\end{array}$ & 1 \\
\hline C & Slovenia & $\begin{array}{l}\text { Almost } 49 \% \text { of children commute actively to and } \\
\text { from school and additional } 12 \% \text { commute actively } \\
\text { from school only. }\end{array}$ & $\begin{array}{l}52 \% \text { of boys and } 50 \% \text { of } \\
\text { girls commute actively to } \\
\text { school }\end{array}$ & $5-15$ years & $\begin{array}{l}\text { To and from } \\
\text { school }\end{array}$ & Not clear & $\begin{array}{l}\text { Analysis of Children's } \\
\text { Development in Slovenia study } \\
\text { (ACDSi) 2013-16 [57,58] }\end{array}$ & 1 \\
\hline C & South Africa & $\begin{array}{l}63 \% \text { of school-aged children walk to school. } 81 \% \text { of } \\
\text { children and adolescents in Cape Town walk to } \\
\text { school without adult supervision in low-income } \\
\text { settings, and } 61 \% \text { of parents reported concerns } \\
\text { about their children safety. }\end{array}$ & Not reported & $6-15$ years & To school & Not clear & $\begin{array}{l}\text { General Household Survey, } \\
2013 \text { [59] and two local studies } \\
\text { conducted in Cape Town, } \\
2016 \text { [60,61] }\end{array}$ & 3 \\
\hline C & Sweden & $\begin{array}{l}48 \% \text { and } 57 \% \text { of children and adolescents used } \\
\text { active transportation to and from school in the } \\
\text { winter and summer months, respectively. }\end{array}$ & Not reported & $6-15$ years & $\begin{array}{l}\text { To and from } \\
\text { school }\end{array}$ & Not clear & $\begin{array}{l}\text { Children's Routes to School Survey } \\
2015-16 \text { [62] }\end{array}$ & 1 \\
\hline C & Thailand & $\begin{array}{l}53.4 \% \text { children and adolescents used active } \\
\text { transportation (walking, cycling, using a } \\
\text { wheelchair, in-line skating or skateboarding) to get } \\
\text { to and from places. }\end{array}$ & $\begin{array}{l}54.7 \% \text { of girls and } 52.4 \% \text { of } \\
\text { boys used active } \\
\text { transportation }\end{array}$ & $6-17$ years & Not specified & Not clear & $\begin{array}{l}\text { Thailand Physical Activity } \\
\text { ChildrenSurvey (TPACS) } 2015 \text { [63] }\end{array}$ & 3 \\
\hline C & Uruguay & $\begin{array}{l}51.2 \% \text { of adolescents between } 13 \text { and } 15 \text { years old } \\
\text { went to the school walking or bicycling } 4 \text { or more } \\
\text { days per week. }\end{array}$ & Not reported & $13-15$ years & To school & $\begin{array}{l}4 \text { or more days } \\
\text { per week }\end{array}$ & $\begin{array}{l}\text { Global School-Based Student } \\
\text { Health Survey (GSHS) } 2012 \text { [64] }\end{array}$ & 3 \\
\hline
\end{tabular}


Table 3. Cont

\begin{tabular}{|c|c|c|c|c|c|c|c|c|}
\hline Grade & Country & Rationale & Gender & Age & $\begin{array}{c}\text { Destination } \\
\text { and Direction }\end{array}$ & Frequency & Source of Information and Year & Profile \\
\hline $\mathrm{C}-$ & Bangladesh & $\begin{array}{l}41.1 \% \text { students aged } 13-17 \text { years used active } \\
\text { transport to commute to or from school at all seven } \\
\text { days prior to the survey. }\end{array}$ & Not reported & $13-17$ years & $\begin{array}{l}\text { To and from } \\
\text { school }\end{array}$ & Last 7 days & $\begin{array}{l}\text { Bangladesh School-based Student } \\
\text { Health Survey (GSHS), } 2014 \text { [65] }\end{array}$ & 2 \\
\hline $\mathrm{C}-$ & Ecuador & $\begin{array}{l}42.7 \% \text { of } 5-17 \text { years-old children reported going to } \\
\text { school or work by foot or bike. }\end{array}$ & Boys: $42 \%$ Girls: $41 \%$ & $5-17$ years & $\begin{array}{l}\text { To school, work } \\
\text { or other } \\
\text { destinations }\end{array}$ & Not clear & Not specified & 3 \\
\hline $\mathrm{C}-$ & England & $\begin{array}{l}\text { On average, } 42.5 \% \text { of children and adolescents used } \\
\text { active modes of transport to school everyday. }\end{array}$ & Not reported & $5-16$ years & To school & Every day & $\begin{array}{l}\text { National Travel Survey } 2016 \text { [66], } \\
\text { Health Survey for England } \\
2015 \text { [67] and Walking and Cycling } \\
\text { Statistics } 2016 \text { [68] }\end{array}$ & 1 \\
\hline C- & France & $\begin{array}{l}44 \% \text { of the 3-10 years old and } 43 \% \text { of the } \\
11-14 \text { years old used active transportation to go to } \\
\text { school according to the National Study of } \\
\text { Individual Nutritional Consumption 2014-2015. } \\
\text { And } 41 \% \text { of the } 6-10 \text {-year-olds reported using } \\
\text { active transportation to school according to the } \\
\text { Health Study of the Environment, Biosurveillance, } \\
\text { Physical Activity, and Nutrition } 2015 \text {. }\end{array}$ & Not reported & 3-14 years & To school & Not clear & $\begin{array}{l}\text { National Study of Individual } \\
\text { Nutritional Consumption (INCA) } \\
\text { 2014-2015 [69] and the Health } \\
\text { Study of the Environment, } \\
\text { Biosurveillance, Physical Activity } \\
\text { and Nutrition (ESTEBAN) } \\
2015 \text { [70] }\end{array}$ & 1 \\
\hline C- & Germany & $\begin{array}{l}\text { Approximately } 40 \% \text { of the children and adolescents } \\
\text { commute actively to school. }\end{array}$ & Not reported & Not specified & To school & Not clear & Not specified & 1 \\
\hline $\mathrm{C}-$ & Lithuania & $\begin{array}{l}45 \% \text { of } 7-8 \text { aged children used active transport to } \\
\text { school and } 57.9 \% \text { used active transport from school } \\
\text { to home. } 84 \% \text { of children and adolescents } \\
\text { (11-13 year) walked to/from school. } 12 \% \text { of youths } \\
\text { and adolescents (15-24 year) reported to engage } \\
\text { regularly in cycling from one point to another. }\end{array}$ & Not reported & $7-24$ years & $\begin{array}{l}\text { To and from } \\
\text { school }\end{array}$ & Not clear & $\begin{array}{l}4 \text { different studies and one special } \\
\text { report Eurobarometer on Sport } \\
\text { and Physical Activity, between } \\
2012 \text { and } 2017 \text { [71-75] }\end{array}$ & 1 \\
\hline $\mathrm{C}-$ & $\begin{array}{l}\text { New } \\
\text { Zealand }\end{array}$ & $\begin{array}{l}45 \% \text { of children and adolescents aged 5-14 years } \\
\text { usually used active transport to school according to } \\
\text { the NZ Health Survey, } 43 \% \text { of children and youth } \\
\text { aged 5-17-year-olds usually used active transport } \\
\text { to and from school according to the Active NZ } \\
\text { Survey. } 30 \% \text { of children aged } 5-12 \text { years and } 31 \% \text { of } \\
\text { adolescents aged } 13-17 \text { years used active transport } \\
\text { to school according to the Health and Lifestyles } \\
\text { Survey and the NZ Household Travel Survey, } \\
\text { respectively. } 24 \% \text { of } 6 \text {-year-olds in a longitudinal } \\
\text { cohort study usually used active transport to get to } \\
\text { and from school. }\end{array}$ & Not reported & $5-17$ years & $\begin{array}{l}\text { To and from } \\
\text { school }\end{array}$ & Not clear & $\begin{array}{l}\text { New Zealand Health Survey } \\
\text { 2016/2017 [76], Active NZ Survey } \\
2018 \text { [77], Health and Lifestyles } \\
\text { Survey 2016 [78], NZ Household } \\
\text { Travel Survey 2015-2018 [79], } \\
\text { and the Growing Up in New } \\
\text { Zealand study 2010 [80] }\end{array}$ & 1 \\
\hline
\end{tabular}


Table 3. Cont

\begin{tabular}{|c|c|c|c|c|c|c|c|c|}
\hline Grade & Country & Rationale & Gender & Age & $\begin{array}{c}\text { Destination } \\
\text { and Direction }\end{array}$ & Frequency & Source of Information and Year & Profile \\
\hline $\mathrm{C}-$ & Portugal & $\begin{array}{l}\text { A study with urban school-aged children showed } \\
\text { that } 45 \% \text { of participants commuted actively to and } \\
\text { from school. Another study in the countryside } \\
\text { region found that } 30 \% \text { of the participants (aged } 7 \text { to } \\
8 \text { years) commuted either by foot or cycling on a } \\
\text { regular basis during school days (ARSA 2012). }\end{array}$ & Not reported & $\begin{array}{l}7-8 \text { years and } \\
15-24 \text { years }\end{array}$ & $\begin{array}{l}\text { To and from } \\
\text { school }\end{array}$ & Not clear & $\begin{array}{l}\text { A study in public schools from the } \\
\text { Porto area [81] and the Health } \\
\text { Study of the Child Population of } \\
\text { the Alentejo Region, 2012 [82] }\end{array}$ & 1 \\
\hline $\mathrm{C}-$ & Taiwan & $\begin{array}{l}33-46 \% \text { of children and adolescents reported } \\
\text { walking or cycling to school most of the days. }\end{array}$ & Not reported & $7-18$ years & To school & Most of the days & $\begin{array}{l}\text { Student Participation in Physical } \\
\text { Activity Survey, } 2015 \text { [83] } \\
\text { and Health Behaviour Survey in } \\
\text { Junior High School Students, } \\
2016 \text { [84] }\end{array}$ & 1 \\
\hline D+ & Australia & $\begin{array}{l}\text { National data shows that } 43 \% \text { of } 12-17 \text { year-olds } \\
\text { usually travel to/from school using active transport, } \\
\text { other state and regional studies shows that } 37 \% \text { of } \\
\text { primary students and } 36 \% \text { of secondary students } \\
\text { use active transport as their usual mode to get } \\
\text { to school. }\end{array}$ & Not reported & $12-17$ years & To school & $\begin{array}{l}\text { Usual } \\
\text { mode-each } \\
\text { week (Usual } \\
\text { defined as at } \\
\text { least } 5 \text { trips out } \\
\text { of } 10 \text { or on at } \\
\text { least } 2.5 \text { school } \\
\text { days) }\end{array}$ & $\begin{array}{l}\text { National Secondary Students Diet } \\
\text { and Activity Survey } \\
\text { 2012-2013 [85], ACT Year } 6 \\
\text { Physical Activity and Nutrition } \\
\text { Survey } 2015 \text { [86], Child Population } \\
\text { Health Survey [87], Queensland } \\
\text { Child Preventive Health Survey } \\
2018 \text { [88], NSW School Physical } \\
\text { Activity and Nutrition Survey } \\
2015 \text { [89], Victorian Child Health } \\
\text { and Wellbeing survey } 2016 \text { [90] }\end{array}$ & 1 \\
\hline D+ & Jersey & $\begin{array}{l}37 \% \text { of } 10-15 \text {-year-olds traveled to school by } \\
\text { active modes. }\end{array}$ & Not reported & $10-15$ years & To school & Not clear & $\begin{array}{l}\text { Health Related Behaviour } \\
\text { Questionnaire } 2014 \text { [91] }\end{array}$ & 1 \\
\hline $\mathrm{D}+$ & Wales & $\begin{array}{l}44 \% \text { primary school children and } 34 \% \text { secondary } \\
\text { school pupils traveled actively to school. In another } \\
\text { survey, } 33.8 \% \text { and } 36.1 \% \text { of children and young } \\
\text { people aged } 11-16 \text { years walked/cycled to and from } \\
\text { school, respectively. }\end{array}$ & Not reported & $11-16$ years & $\begin{array}{l}\text { To and from } \\
\text { school }\end{array}$ & Not clear & $\begin{array}{l}\text { National Survey for Wales } \\
\text { (2016-17) [92] and The Health } \\
\text { Behaviour of School-aged Children } \\
\text { (HBSC)/School Health Research } \\
\text { Network (SHRN) Survey } 2017 \text { [93] }\end{array}$ & 1 \\
\hline $\mathrm{D}$ & Estonia & $\begin{array}{l}\text { The percentage of use of active transport varied } \\
\text { between } 36-56 \% \text {. Specifically, } 35 \% \text { of children } \\
\text { walked to school and back home, while } 14 \% \text { of } \\
\text { children rode a bike to go to school. The grading } \\
\text { process took into account the number of subjects, } \\
\text { age range and used methodology of different } \\
\text { studies. }\end{array}$ & Not reported & $7-17$ years & $\begin{array}{l}\text { To and from } \\
\text { school }\end{array}$ & Not clear & $\begin{array}{l}\text { Children's Physical Activity Study } \\
2015 \text { and Schools in Motion } \\
\text { Survey } 2018 \text { [94] }\end{array}$ & 1 \\
\hline $\mathrm{D}$ & $\begin{array}{l}\text { Guernsey } \\
\text { Channel } \\
\text { Islands }\end{array}$ & $\begin{array}{l}\text { On average, } 31 \% \text { of children and adolescents } \\
\text { reported active travel (walking, bicycle or scooter) } \\
\text { to school on the day of the survey ( } 43 \% \text { of primary } \\
\text { school pupils and } 25 \% \text { of secondary pupils. }\end{array}$ & Not reported & $\begin{array}{l}\text { Primary and } \\
\text { secondary } \\
\text { (grades 6,8 } \\
\text { and 10) }\end{array}$ & To school & $\begin{array}{l}\text { On the day of } \\
\text { the survey }\end{array}$ & $\begin{array}{l}\text { Guernsey Young People Survey } \\
\text { 2016-2017 [95] }\end{array}$ & 1 \\
\hline
\end{tabular}


Table 3. Cont.

\begin{tabular}{|c|c|c|c|c|c|c|c|c|}
\hline Grade & Country & Rationale & Gender & Age & $\begin{array}{c}\text { Destination } \\
\text { and Direction }\end{array}$ & Frequency & Source of Information and Year & Profile \\
\hline $\mathrm{D}$ & Lebanon & $\begin{array}{l}36.8 \% \text { of Lebanese adolescents between the ages of } \\
13 \text { and } 18 \text { reported walking or biking to school. }\end{array}$ & Not reported & $13-17$ years & To school & Not clear & $\begin{array}{l}\text { Global School-Based Student } \\
\text { Health Survey } 2016 \text { (GSHS) [96] }\end{array}$ & 1 \\
\hline D- & Canada & $\begin{array}{l}21 \% \text { of } 5 \text { - to } 19 \text {-year-olds in Canada typically use } \\
\text { active modes of transportation (e.g., walk, bike), } \\
\text { and } 16 \% \text { use a combination of active and inactive } \\
\text { modes of transportation to travel to and from } \\
\text { school (2014-16 CANPLAY, CFLRI). }\end{array}$ & Not reported & 5 to 19 & $\begin{array}{l}\text { To and from } \\
\text { school }\end{array}$ & Typical use & Kids CANPLAY 2014-2016 [97] & 1 \\
\hline $\mathrm{D}-$ & $\begin{array}{l}\text { United } \\
\text { States }\end{array}$ & $\begin{array}{l}38 \% \text { of adolescents walked or used a bicycle for at } \\
\text { least } 10 \text { min continuously once or more in a typical } \\
\text { week to get to and from places, and } 23 \% \text { of youth } \\
\text { actively commuted 5-7 days per week. }\end{array}$ & $\begin{array}{l}45 \% \text { of boys and } 32 \% \text { of } \\
\text { girls reported any active } \\
\text { transportation in a } \\
\text { typical week }\end{array}$ & $12-19$ years & $\begin{array}{l}\text { To and from } \\
\text { multiple places }\end{array}$ & $\begin{array}{l}5 \text { to } 7 \text { days on a } \\
\text { typical week }\end{array}$ & $\begin{array}{l}\text { National Health and Nutrition } \\
\text { Examination Survey (NHANES } \\
\text { 2015-16) [98] }\end{array}$ & 1 \\
\hline $\mathrm{F}$ & Chile & $\begin{array}{l}15 \% \text { of children and youth (weighted average) rode } \\
\text { a bike or walked to and from school (ranging from } \\
0.29 \% \text { to } 32.2 \% \text { in different samples and regions). }\end{array}$ & Not reported & Not specified & $\begin{array}{l}\text { To and from } \\
\text { school }\end{array}$ & Not clear & $\begin{array}{l}\text { National Survey of Quality of life } \\
\text { 2015-2016 (ENCAVI) [99], Survey } \\
\text { of Urban Quality of Life } \\
\text { Perception } 2015 \text { (EPCVU) [100], a } \\
\text { cross-sectional study of seventh } \\
\text { grade students in the Maule region } \\
2014 \text { [101], and a cross-sectional } \\
\text { study in Valparaiso } 2017 \text { [102] }\end{array}$ & 1 \\
\hline INC & $\begin{array}{l}\text { United Arab } \\
\text { Emirates }\end{array}$ & $\begin{array}{l}\text { There was no current data available to grade } \\
\text { this indicator. }\end{array}$ & NA & NA & NA & NA & NA & 1 \\
\hline $\mathrm{N} / \mathrm{A}$ & Qatar & $\begin{array}{l}\text { Active transportation indicator is excluded from the } \\
\text { report according to stakeholders' group } \\
\text { recommendation. This indicator is still not } \\
\text { applicable in Qatar due to unsafe roads and the hot } \\
\text { climate during most times of the year. }\end{array}$ & N/A & N/A & N/A & $\mathrm{N} / \mathrm{A}$ & N/A & 1 \\
\hline
\end{tabular}

Abbreviations: INC, incomplete; NA, not applicable. 
Table 4. Descriptive statistics of the latent variables by country profile.

\begin{tabular}{ccccccccccccc}
\hline \multirow{2}{*}{$\begin{array}{c}\text { Profile (\% of } \\
\text { Countries) }\end{array}$} & \multicolumn{3}{c}{ Active Transportation Grade } & \multicolumn{3}{c}{ Human Development Index } & \multicolumn{4}{c}{ Gini Index } \\
\cline { 2 - 12 } & Mean & SD & Min & Max & Mean & SD & Min & Max & Mean & SD & Min & Max \\
\hline $1 n=25(51 \%)$ & 6.08 & 2.55 & 0.00 & 10.00 & 0.89 & 0.05 & 0.763 & 0.985 & 33.78 & 5.29 & 25.44 & 47.70 \\
$2 n=7(14.3 \%)$ & 10.14 & 2.34 & 7.00 & 13.00 & 0.55 & 0.06 & 0.448 & 0.624 & 38.29 & 4.81 & 32.40 & 43.20 \\
$3 n=17(34.7 \%)$ & 9.82 & 1.88 & 7.00 & 13.00 & 0.80 & 0.09 & 0.666 & 0.925 & 42.08 & 10.58 & 27.10 & 63.0 \\
\hline
\end{tabular}

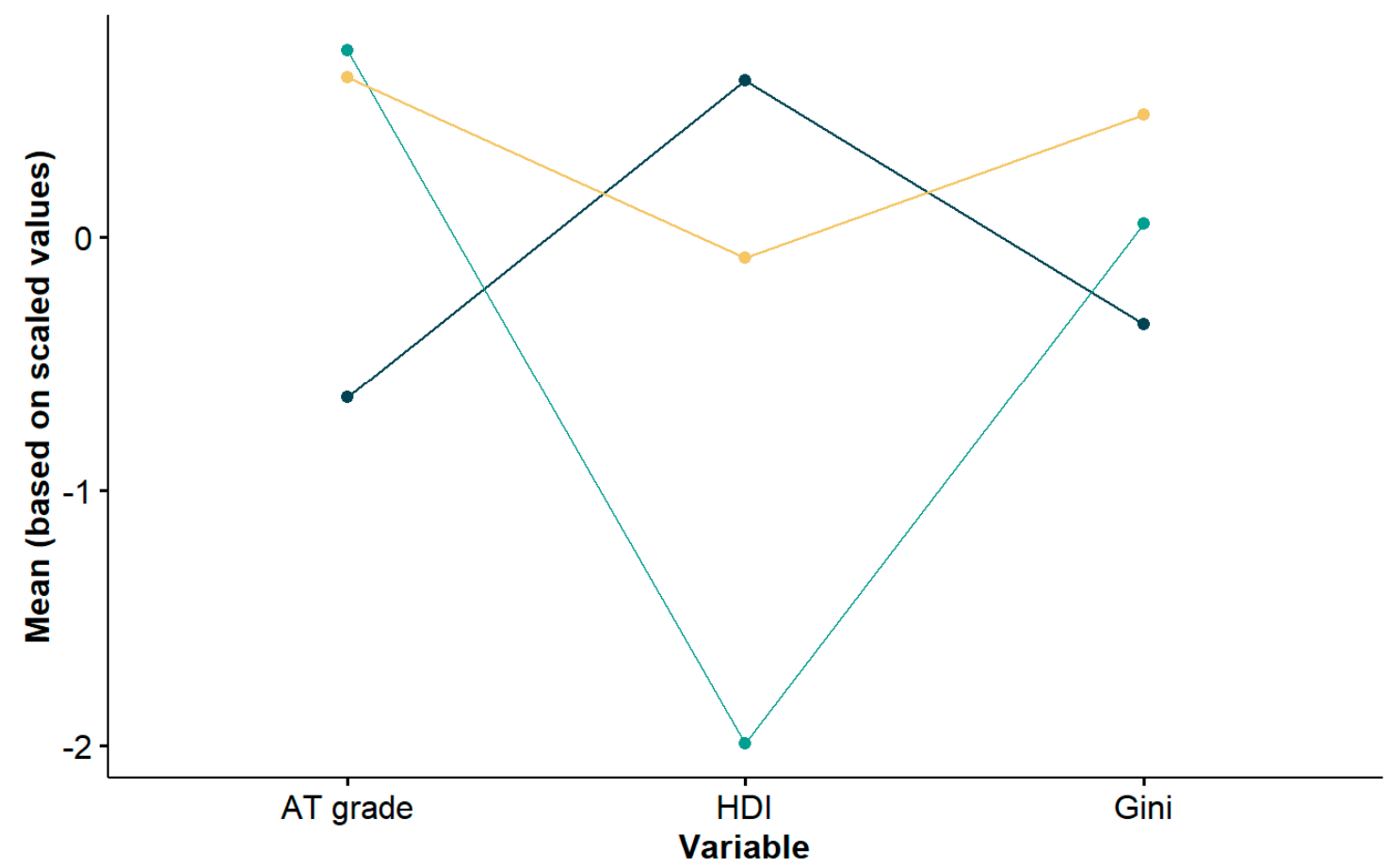

Figure 1. Country profiles for active transportation and sociodemographic variables of countries in the Global Matrix 3.0. The range of values for the active transportation grade, Human Development Index and the Gini index varied notably between variables, therefore they were converted to z-scores to be expressed in the same range of values and to ease their graphic depiction.

The availability of details related to active transportation in the report cards, beyond the reported prevalence, varied across countries. Table 5 summarizes the information provided by countries in terms of practices and policies, strategies proposed to improve the grades and research gaps identified by expert groups in each country. Twenty-four countries provided at least one of these details. The policies and practices identified by the expert groups included school siting policies, transport policies that prioritize active modes of commuting, walking challenges and special events, and multi-component programs that comprise educational strategies, enforcement of regulation to improve traffic safety, and providing infrastructure and resources at several levels (children, teachers, schools and communities). The most common topics in the strategies proposed to improve the grades were improving safety conditions, providing supportive infrastructure, developing informational and education strategies, and involving parents, schools and communities in the promotion of active transportation. Several research gaps were identified, but the most frequent across countries was the need to study active transportation to destinations other than school (Table 5). 
Table 5. Policies and practices, strategies to improve the grade and research gaps in active transportation identified in the Global Matrix 3.0.

\begin{tabular}{|c|c|c|c|c|c|}
\hline Grade & Country & Profile & Policies/Practices & How to Improve the Grade & Gaps \\
\hline A- & Japan & 3 & $\begin{array}{l}\text { Since } 1953 \text { Japan has a "walking to school practice" resulting from the implementation } \\
\text { of the article } 49 \text { of the School Education Act, which regulates the siting of public schools } \\
\text { in urban areas of Japan. This article establishes that the commuting distances are } 4 \mathrm{~km} \\
\text { for elementary schools and } 6 \mathrm{~km} \text { for junior high schools. Based on these, the boards of } \\
\text { education must ensure that children attend to schools located within those distances to } \\
\text { allow children to walk to school }[14,103,104] \text {. }\end{array}$ & Not reported & $\begin{array}{l}\text { Research on active transportation to destinations } \\
\text { other than schools (e.g., going shopping, going to the } \\
\text { park, sports clubs or cram schools) [104]. }\end{array}$ \\
\hline A- & Zimbabwe & 2 & Not reported & $\begin{array}{l}\text { 1. Through public health messages to } \\
\text { highlight the benefits of active transportation } \\
\text { and reduce the prestige/status symbol } \\
\text { associated with motorized transportation. } \\
\text { 2. Implementing policies that encourage and } \\
\text { provide safe and walkable neighborhoods } \\
\text { and bike lanes, etc. [105]. }\end{array}$ & $\begin{array}{l}\text { There is a need of data reporting the time invested in } \\
\text { active transportation and distance to and from school, } \\
\text { as well as research data on the correlates of active } \\
\text { transportation, and more recent data is required [105]. }\end{array}$ \\
\hline $\mathrm{B}+$ & Finland & 3 & Not reported & Not reported & $\begin{array}{l}\text { There is no comparable published data available } \\
\text { about active school commutes for upper secondary } \\
\text { students when the distance between home and school } \\
\text { is less than } 5 \mathrm{~km} \text {. More information is needed about } \\
\text { active transportation to other destinations [106]. }\end{array}$ \\
\hline $\mathrm{B}+$ & Hong Kong & 3 & $\begin{array}{l}\text { The high density of Hong Kong could be one of the factors facilitating active } \\
\text { transportation to school. Since most districts in Hong Kong are highly self-contained, } \\
\text { children can attend schools located at walkable distance from their home [107,108]. }\end{array}$ & $\begin{array}{l}\text { 1. Encouraging active travel to destinations } \\
\text { other than school may provide additional } \\
\text { health benefits for children and adolescents. } \\
\text { 2. Promoting cycling to and from school and } \\
\text { other destinations in districts with a bicycle } \\
\text { track }[107,108] \text {. }\end{array}$ & $\begin{array}{l}\text { Data about active transportation to destinations other } \\
\text { than school, as well as the relationship between active } \\
\text { transportation, physical activity and health-related } \\
\text { outcomes. Also, data on the duration of active travel } \\
\text { trips is required [107,108]. }\end{array}$ \\
\hline B & Colombia & 3 & $\begin{array}{l}\text { In Bogota, the capital city of Colombia, the program "Bike to school" is implemented in } \\
\text { public schools to promote cycling as a sustainable mode of transportation to school and } \\
\text { other destinations in the city. The program was created in order to address the barriers } \\
\text { to access to education and to decrease the dropout rates. Bike to school program } \\
\text { includes the following strategies: (a) bicycle loan, (b) workshops on skills and abilities } \\
\text { to ride a bicycle, (c) basic mechanics and road safety education, (d) participatory } \\
\text { mapping of safe routes, (e) daily trips from a meeting point to school with adult } \\
\text { supervision, and (f) extracurricular activities to develop responsible behaviours in the } \\
\text { roads and to visit other destinations of interest in the city [109,110]. } \\
\text { Another promising practice to encourage walking and cycling, but with recreational } \\
\text { purposes, are the Open Streets programs, or Ciclovias. Colombia currently has } 67 \text { of } \\
\text { these programs that close main roads to motorized vehicles and open them for leisure } \\
\text { activities on Sundays and holidays [109,111]. Walking and cycling are the main } \\
\text { activities performed by children who attend Ciclovia in Bogota [112]. } \\
\text { Also, Colombia has a specific law to support the use of bicycles as the main mode of } \\
\text { transport at the national level (Law } 1811 \text { of 2016). This law establishes the responsibility } \\
\text { of public transportation systems to allow multi-modal trips through the provision of } \\
\text { bike-supporting infrastructure, and encourages schools to implement programs to } \\
\text { promote cycling [113]. }\end{array}$ & $\begin{array}{l}\text { 1. Improving safety conditions and } \\
\text { infrastructure to keep promoting and } \\
\text { maintaining active transportation as a } \\
\text { desirable behaviour since early ages [109]. }\end{array}$ & Not reported \\
\hline
\end{tabular}


Table 5. Cont.

\begin{tabular}{|c|c|c|c|c|c|}
\hline Grade & Country & Profile & Policies/Practices & How to Improve the Grade & Gaps \\
\hline B & Nigeria & 2 & $\begin{array}{l}\text { The National Transport Policy in Nigeria is under review with the aim to strengthen the } \\
\text { inclusion of non-motorized transport infrastructure and to create better non-motorized } \\
\text { transport options for urban residents. This review is the result of a workshop on streets } \\
\text { design led by the Federal Ministry of Transport in } 2017 \text { and is a good example of the } \\
\text { concerted efforts to improve the conditions for active transportation in Nigeria [114,115]. } \\
\text { Another example is the Non-Motorized Transport Policy developed in Lagos, which } \\
\text { aims to prioritize walking, cycling and public transportation as the main modes of } \\
\text { transport [114]. This policy specifically addresses active transportation to school } \\
\text { through two strategies: (a) public awareness through the creation of a curriculum about } \\
\text { road safety and benefits of active transportation for primary and secondary school } \\
\text { students. And (b) regulations that include the creation of route plans for students to go } \\
\text { to school, and the implementation of access and safety measures such as speed limits, } \\
\text { traffic calming infrastructure and school zone signaling [116]. }\end{array}$ & Not reported & Not reported \\
\hline $\mathrm{C}+$ & Ghana & 2 & $\begin{array}{l}\text { The Community Day Senior High Schools, built in various districts in Ghana, seem to } \\
\text { be encouraging active transportation to school. The students who attend to this schools } \\
\text { usually walk to and from school every day, some of them covering more than two } \\
\text { kilometers [117]. }\end{array}$ & Not reported & Not reported \\
\hline $\mathrm{C}+$ & Mexico & 3 & Not reported & $\begin{array}{l}\text { 1. Promoting active transportation among } \\
\text { Mexican children and adolescents. } \\
\text { 2. Communities and governments should } \\
\text { provide appropriate safety conditions on } \\
\text { streets, sidewalks and neighborhoods to } \\
\text { promote walking and cycling among } \\
\text { children and adolescents [118]. }\end{array}$ & $\begin{array}{l}\text { Data on all age groups and stratified by age group } \\
\text { and sex is desirable for future surveys [118]. }\end{array}$ \\
\hline C & Brazil & 3 & Not reported & $\begin{array}{l}\text { Local authorities should be encouraged to } \\
\text { create a monitoring system to generate } \\
\text { standardized and detailed reports on active } \\
\text { transportation to school to support planning } \\
\text { and evaluation of public policies [119]. }\end{array}$ & $\begin{array}{l}\text { Data on time invested in active transportation, } \\
\text { the distance to the school and other environmental } \\
\text { and mobility-related factors such as bike paths, traffic } \\
\text { and conditions of the city is lacking [52]. }\end{array}$ \\
\hline C & Ethiopia & 2 & Not reported & $\begin{array}{l}\text { 1. Building sidewalks to encourage active } \\
\text { transportation in all cities in Ethiopia. } \\
\text { 2. Encouraging and supporting children and } \\
\text { adolescents to travel to and from school } \\
\text { through active transportation [120]. }\end{array}$ & $\begin{array}{l}\text { Active transportation specific studies in Ethiopia are } \\
\text { required [120]. }\end{array}$ \\
\hline C & Scotland & 1 & Not reported & Not reported & $\begin{array}{l}\text { No data available on active commuting to and from } \\
\text { places other than school [121]. }\end{array}$ \\
\hline C & Sweden & 1 & $\begin{array}{l}\text { A national cycling strategy has been adopted in Sweden to improve safety and increase } \\
\text { cycling [122]. The strategy aims to increase cycling through five action lines: (a) } \\
\text { creating more bicycle-friendly municipalities, (b) focusing on various types of cyclists } \\
\text { (where children are highlighted as a population of interest), (c) giving higher priority to } \\
\text { bicycle traffic in community planning, (d) building more functional and user-friendly } \\
\text { cycling infrastructure and (e) strengthening research an innovation on cycling [123]. }\end{array}$ & Not reported & Not reported \\
\hline
\end{tabular}


Table 5. Cont.

\begin{tabular}{|c|c|c|c|c|c|}
\hline Grade & Country & Profile & Policies/Practices & How to Improve the Grade & Gaps \\
\hline C & Uruguay & 3 & Not reported & $\begin{array}{l}\text { Creating policies to encourage the creation of } \\
\text { cycle lanes and safe sidewalks. }\end{array}$ & $\begin{array}{l}\text { Data on active transportation in a wider age range } \\
\text { and to locations other than school. }\end{array}$ \\
\hline C- & Ecuador & 3 & Not reported & $\begin{array}{l}\text { Reinforcing programs aiming to promote } \\
\text { active transportation [124]. }\end{array}$ & Not reported \\
\hline C- & France & 1 & Not reported & Not reported & $\begin{array}{l}\text { Research is needed on the characteristics of active } \\
\text { transportation of children and adolescents (frequency, } \\
\text { mode, distance covered) and on the potential barriers } \\
\text { to this in order to develop effective promotion } \\
\text { program [125]. }\end{array}$ \\
\hline C- & Lithuania & 1 & Not reported & $\begin{array}{l}\text { 1. Promoting and facilitating safe active } \\
\text { transport to get to school and other } \\
\text { destinations. } \\
\text { 2. Prioritizing active transportation } \\
\text { promotion as a key factor at schools and } \\
\text { communities. } \\
\text { 3. Involving parents, schools, community } \\
\text { and policy makers in the promotion of active } \\
\text { transportation [71]. }\end{array}$ & $\begin{array}{l}\text { 1. Research on the prevalence and trends of active } \\
\text { transport in Lithuania, considering the most popular } \\
\text { modes of active transportation used to get to/from } \\
\text { different points or destinations (e.g., parks, shops, } \\
\text { sport fields) among children and adolescents as well } \\
\text { as studying the role of active transport in achieving } \\
\text { recommended levels of physical activity. } \\
\text { 2. Research on health and social benefits of active } \\
\text { transportation is needed. } \\
\text { 3. Evaluating the impact of the cycling paths and } \\
\text { interventions at the school, community and } \\
\text { municipality levels. } \\
\text { 4. Examining the potential moderators and mediators } \\
\text { of active transport behaviour change to help refine } \\
\text { interventions [71]. }\end{array}$ \\
\hline C- & $\begin{array}{c}\text { New } \\
\text { Zealand }\end{array}$ & 1 & Not reported. & $\begin{array}{l}\text { Strategies to encourage active travel to } \\
\text { school are needed, especially for girls, } \\
\text { younger children, and older } \\
\text { adolescents [126]. This strategies should } \\
\text { have a multi-sectoral y culturally } \\
\text { appropriate approach, including urban } \\
\text { planning, initiatives a the school and } \\
\text { community level, social marketing } \\
\text { campaigns and family support [127]. }\end{array}$ & $\begin{array}{l}\text { Nationally representative data on active } \\
\text { transportation to school and other destinations that is } \\
\text { comparable between countries and across time is } \\
\text { desirable [127]. }\end{array}$ \\
\hline C- & Taiwan & 1 & Not reported & $\begin{array}{l}\text { Local governments and schools should work } \\
\text { together to create a safe and convenient } \\
\text { environment for active transportation [128]. }\end{array}$ & $\begin{array}{l}\text { Research on the contribution of active transportation } \\
\text { to overall physical activity in children and } \\
\text { adolescents, and about motivations and barriers for } \\
\text { active transportation is needed [128]. }\end{array}$ \\
\hline
\end{tabular}


Table 5. Cont.

\begin{tabular}{|c|c|c|c|c|c|}
\hline Grade & Country & $\begin{array}{l}\text { Profile } \\
\end{array}$ & Policies/Practices & How to Improve the Grade & Gaps \\
\hline \multirow[t]{2}{*}{ D+ } & \multirow[t]{2}{*}{ Australia } & \multirow[t]{2}{*}{1} & $\begin{array}{l}\text { The Australian Capital Territory has implemented the Ride or Walk to School program } \\
\text { since } 2012 \text { aiming to build the capacity of primary schools to support and promote } \\
\text { active travel to and from school. The program was designed with a participatory } \\
\text { approach including students and different stakeholders. The strategies of the program } \\
\text { include: (a) resources for teachers and students, (b) provision of bikes and helmets, (c) } \\
\text { safe routes maps, (d) workshops to increase skills, and (e) four annual active travel } \\
\text { events. This program was expanded to high schools since } 2016 \text { [129]. } \\
\text { In Western Australia, the Department of Transport implemented the program "Your } \\
\text { Move Schools". This is a community-focused program that promotes active and } \\
\text { sustainable transportation providing: (a) teaching resources, (b) expert advice and (c) } \\
\text { access to funding (up to } \$ 5000 \text { AUD) to promote active transportation through bike } \\
\text { education workshops, wayfinding, bike supporting infrastructure like bike shelters, } \\
\text { bike repair stations, bike skills tracks and bicycle parkings [129]. }\end{array}$ & $\begin{array}{l}\text { 1. Encouraging families to active commute } \\
\text { at least part of the way, promoting the use of } \\
\text { park and walk/ride/scoot zones away from } \\
\text { school grounds to reduce traffic. } \\
\text { 2. Creating and promoting safe routes to } \\
\text { schools and engage schools to promote their } \\
\text { use. } \\
\text { 3. Creating greater awareness of actual } \\
\text { distances between home and school and the } \\
\text { travel time for active modes. } \\
4 \text {. Highlighting the benefit of students } \\
\text { travelling to school carrying their school } \\
\text { bags as an opportunity to be active while } \\
\text { carrying a load, which could contribute to } \\
\text { improve their muscular fitness [129]. }\end{array}$ & $\begin{array}{l}\text { 1. Nationally representative data for primary and } \\
\text { secondary students. } \\
\text { 2. Data on the use of active transportation to other } \\
\text { destinations. } \\
\text { 3. Data on the use of multi-modal transport } \\
\text { combining active transport with public transport. } \\
\text { 4. Research about how far families and children are } \\
\text { willing to travel using active transportation [129]. }\end{array}$ \\
\hline & & & $\begin{array}{l}\text { In the Northern Territory, the Nightcliff Walk and Wheel initiative is aimed at } \\
\text { encouraging students to walk and cycle to school. This is a local project in two dense } \\
\text { suburbs lead by principals and parents from four schools. The project has a focus on } \\
\text { roads safety for children and has implemented activities such as the Ride2School days, } \\
\text { increasing cycling to school [129]. }\end{array}$ & & \\
\hline $\mathrm{D}+$ & Wales & 1 & $\begin{array}{l}\text { The report card mentioned the following initiatives led by charities to promote active } \\
\text { travel to school: } \\
\text { 1. Active Journeys-Sustrans School active travel program promotes active } \\
\text { transportation through different actions like: (a) providing support to schools to } \\
\text { develop active travel plans, (b) delivering activities and lessons, (c) offering free } \\
\text { incentives to promote active travel, (d) providing resources and online travel challenges } \\
\text { for the school community, and (e) rewarding schools with the School Mark award for } \\
\text { achieving excellence in active and sustainable travel [130]. } \\
\text { 2. Living Streets Walking initiatives: This charity has two main strategies for schools, } \\
\text { the WOW Year-Round Walk to School challenge and the Five-Days Walking challenge. } \\
\text { Both of these aim to engage primary and secondary students to walk to school } \\
\text { encouraging them with an interactive travel tracker and the provision of incentives at } \\
\text { the end of the challenge. This charity also encourages the celebration of the Walk to } \\
\text { School Week in May every year [131]. }\end{array}$ & Not reported & $\begin{array}{l}\text { More research is needed on how children and young } \\
\text { people travel to other places including shops, parks } \\
\text { and friends' or relatives' houses [132]. }\end{array}$ \\
\hline \multirow[t]{2}{*}{$\mathrm{D}$} & \multirow[t]{2}{*}{$\begin{array}{l}\text { Guernsey } \\
\text { Channel } \\
\text { Islands }\end{array}$} & & $\begin{array}{l}\text { Guernsey has an integrated transport strategy in place that promotes active travel with } \\
\text { the aim of having a positive impact on the environment and the population's } \\
\text { health [133]. The On-island Integrated Transport Strategy aims to encourage active } \\
\text { travel, followed by the use of public transport and to reduce the use of private motor } \\
\text { vehicles. This strategy was initially planned to progressively advance to a taxation } \\
\text { policy for high emission vehicles to support the promotion of active travel. }\end{array}$ & $\begin{array}{l}\text { Through the implementation of the } \\
\text { integrated transport initiative that supports } \\
\text { active travel [133]. }\end{array}$ & Not reported \\
\hline & & & $\begin{array}{l}\text { However, there are other actions in this strategy aimed at increasing active travel to } \\
\text { school, such as: (a) Bikeability training at primary schools, (b) increasing the } \\
\text { investments in walking and cycling infrastructure to improve safety for active } \\
\text { commuters, (c) revising the speed limits to enhance the safety of vulnerable populations } \\
\text { using active travel, and (d) developing and implementing travel plans for schools [134]. }\end{array}$ & & \\
\hline
\end{tabular}


Table 5. Cont.

\begin{tabular}{|c|c|c|c|c|c|}
\hline Grade & Country & Profile & Policies/Practices & How to Improve the Grade & Gaps \\
\hline D & Lebanon & 1 & Not reported & Not reported & $\begin{array}{l}\text { Nationally representative samples for children and } \\
\text { adolescents and on all active transportation means are } \\
\text { required to gain a better understanding of this } \\
\text { indicator [135,136]. }\end{array}$ \\
\hline \multirow[t]{2}{*}{ D- } & \multirow[t]{2}{*}{ Canada } & \multirow[t]{2}{*}{1} & $\begin{array}{l}\text { In Ontario, the Minister of Education expanded the funding for initiatives that improve } \\
\text { the cognitive, physical, social and emotional well-being of students. Specifically } \\
\text { walking school buses and biking-to-school programs have benefited from this increase } \\
\text { in the funding [137]. These initiatives are part of the Ontario Active School Travel } \\
\text { program (formerly Active \& Safe Routes to School) which comprise five components: } \\
\text { (a) education activities to foster the skills, confidence, and awareness such as } \\
\text { workshops and route mapping. (b) Encouragement activities to inspire students, } \\
\text { parents and school staff to try active travel modes. For example, walk and wheel } \\
\text { seasonal events or walking school buses. (c) Engineering actions to create safe and } \\
\text { accessible school sites, neighbourhoods and routes to school, such as school siting, } \\
\text { signaling, parking restrictions, crosswalk improvements or crossing guards. (d) } \\
\text { Enforcement of traffic policies to improve safety around schools. (e) Evaluations to } \\
\text { measure the measure success, and demonstrate impact of the actions [138]. }\end{array}$ & $\begin{array}{l}\text { 1. Creating a culture of active transportation, } \\
\text { to make active transportation the norm. } \\
\text { 2. Establishing lower speed limits in school } \\
\text { areas. } \\
\text { 3. Implementing traffic-calming devices (e.g., } \\
\text { speed bumps/humps, chicanes, narrower } \\
\text { intersections) to enhance compliance with } \\
\text { speed limits, mainly in low-income areas, } \\
\text { where more children engage in active } \\
\text { transportation. } \\
\text { 4. Hiring more crossing guards at busy } \\
\text { intersections near schools. } \\
\text { 5. Considering more progressive policies for } \\
\text { low-income areas, to access to funding for } \\
\text { active transportation interventions. } \\
\text { 6. Considering children's active } \\
\text { transportation when planning schools and } \\
\text { recreation facilities. }\end{array}$ & $\begin{array}{l}\text { 1. Research on activetransportation to destinations } \\
\text { such as parks, stores, recreation facilities and other } \\
\text { places. } \\
\text { 2. Studies on children's preferences for cycling and } \\
\text { how to harness them in interventions. } \\
\text { 3. More research is needed on how to facilitate } \\
\text { children's independent mobility. } \\
\text { 4. More research is needed on the use of mixed modes } \\
\text { of transportation to and from destinations [137]. }\end{array}$ \\
\hline & & & $\begin{array}{l}\text { In 2017, three organizations in Canada (Canada Bikes, Green Communities Canada and } \\
\text { the National Active and Safe Routes to School Working Group) created an active } \\
\text { transportation alliance to advocate for the adoption and funding of a national active } \\
\text { transportation strategy [137]. However, this strategy is not yet in place. }\end{array}$ & $\begin{array}{l}\text { 7. Encouraging schools to implement } \\
\text { "drop-off spots" from which driven children } \\
\text { could safely walk to school in groups [137]. }\end{array}$ & \\
\hline D- & $\begin{array}{l}\text { United } \\
\text { States }\end{array}$ & 1 & $\begin{array}{l}\text { Safe Routes to School is a movement with initiatives at the regional, state and local } \\
\text { levels that aims to promote walking and bicycling to school, improving safety, health } \\
\text { and physical activity levels. Actions at the local level incorporate the six E's integrated } \\
\text { approach: (a) education through the provision of training in skills and knowledge to } \\
\text { walk and bicycle safely and teaching the benefits of active transportation. (b) } \\
\text { Encouragement to motivate children to travel actively through events and activities. (c) } \\
\text { Engineering to improve streets and neighborhoods in order to make them more } \\
\text { convenient for walking and bicycling. (d) Enforcement of safety regulation. (e) } \\
\text { Evaluation of the success and opportunities to improve the initiatives in place. And (f) } \\
\text { equity to ensure that the program benefits all demographic groups. Actions at the } \\
\text { regional and state level are focused on finding funding and ensuring the proper use of } \\
\text { the resources invested in the program. At the federal level, the Safe Routes Partnership } \\
\text { advocates for policy and funding support and provides expert help, ideas and resources } \\
\text { for the leaders at all levels [139]. }\end{array}$ & $\begin{array}{l}\text { 1. Investing in infrastructure, programs, } \\
\text { and policies that promote active } \\
\text { transportation to and from school. } \\
\text { 2. Allocating funding to provide and } \\
\text { improve infrastructure to encourage active } \\
\text { transportation (e.g., sidewalks, crosswalks, } \\
\text { bike lanes, trails, etc.). } \\
\text { 3. Encouraging children at home to use } \\
\text { active transportation to school and other } \\
\text { neighborhood locations. } \\
\text { 4. Investing in infrastructure and policies } \\
\text { such as Safe Routes to School and walking } \\
\text { school buses. } \\
\text { 5. Informing parents (at all income levels) } \\
\text { about the benefits of active } \\
\text { transportation [140]. }\end{array}$ & $\begin{array}{l}\text { 1. The study of locations where children and } \\
\text { adolescents walk and bike, duration and distance of } \\
\text { trips as well as the main reasons for not engaging in } \\
\text { active transportation. } \\
\text { 2. Surveillance systems should include children under } \\
12 \text { years old [140]. }\end{array}$ \\
\hline
\end{tabular}




\section{Discussion}

Our results suggest that about half of children and adolescents use active modes of transportation to get to and from places, mainly to and/or from school. However, a pooled estimate of the global prevalence of active transportation cannot be calculated from the Global Matrix 3.0 data for reasons that will be discussed below. Despite the clear gradient in average grades according to HDI that has been discussed in previous publications [141-143], our results show variability within HDI groups and the LPA allowed us to examine the clustering of this sample of countries according to three variables of interest (active transportation grades, level of development and income inequality).

\subsection{Comparability of Data}

There was wide variability between countries in the prevalence of active transportation, and high involvement in this behaviour was reported across countries with very different socioeconomic contexts (e.g., Japan, Zimbabwe, Nepal, Denmark and Finland). However, the data reported by the countries presented in Table 3 show important methodological differences that should be accounted for when comparing the prevalence of active transportation between countries. One of the issues that can affect the comparability of data is the difference in the frequency of use of active transportation reported by the countries. Depending on the cut-point used to define children as active travelers, the prevalence will vary widely, and the use of active transportation can be overestimated or underestimated. Similarly, the prevalence may vary depending on the direction of active transportation assessed since different modes can be used to go to and from school. As observed in previous comparisons of surveillance systems measuring active transportation, the prevalence of active transportation varies greatly according to the construct assessed [144]. In the group of countries included in this analysis, the frequencies reported varied from daily to at least twice per week. Even when the source of information was the same survey (e.g., the GSHS across countries), different frequencies were reported [136,145-147]. Regarding the construct assessed, the destination for active transportation is also relevant. Despite the broad definition of active transportation in the Global Matrix 3.0 benchmarks [14], most of the evidence available on active transportation in children is focused on the journeys to and from school, as observed in this analysis and in previous literature [148]. Only Ecuador and the United States reported the use of active transportation to other destinations, which could suggest an underestimation of the involvement in active transportation in other countries since trips to places such as parks and other people's homes are also relevant opportunities to engage in this behaviour [149]. These findings point to a need for the development of harmonized and contextualized measurements. Our results are consistent with the findings reported by Herrador-Colmenero et al. in a systematic review, in which the formulation of a standardized question is proposed to overcome the heterogeneity in measures to assess active transportation [150]. Based on these insights, initiatives like the Global Matrix and organizations like the AHKGA can contribute to the improvement of surveillance systems for the evaluation of active transportation among children.

The Global Matrix initiative aims to better understand the global variation of certain physical activity indicators [14]. Specifically, active transportation is one of the most strategic indicators in the Global Matrix 3.0 to contribute to this aim, due to the low amount of INC grades, and the good dispersion of grades across countries [14]. However, the availability of transportation-relevant contextual variables at the country level to understand these variations was limited. Therefore, the LPA provides an exploratory approach to identify subgroups that share similar patterns of variables $[20,151]$, and provides a unique opportunity to identify the ways in which countries in the Global Matrix 3.0 cluster, according to the grades for active transportation and contextual variables. The identified profiles can be useful for the discussion of the different contexts in which active transportation needs to be maintained or increased. A description of the three profiles is provided below. 


\subsection{Country Profiles for Active Transportation and Sociodemographic Variables}

Profile 1 included mainly countries with a very high HDI and low income inequality, mostly with a reported prevalence of active transportation under 50\%. Mainly, countries from North America, Europe and Oceania were grouped in this profile. While the countries with the lowest prevalence of active transportation were classified in this group (Chile, the United States and Canada), it also included some countries with non-negligible prevalence of active transportation such as the Netherlands, Belgium and the Czech Republic. This means that although all of these countries have a similar development level, there are other relevant factors influencing active travel among children. First, some of these are countries where long distances between destinations and the perceived convenience of driving may undermine opportunities for active travel [102,152-154]. Second, urban planning and policies that have prioritized people instead of cars, as well as supportive infrastructure have made active modes a convenient and safe alternative to commute $[155,156]$. Interventions in countries under this profile should aim to increase active transportation addressing the issues of distance and convenience, attempting to discourage the use of motorized vehicles for short trips, and trying to shift the social norms to consider active modes the default option for commuting as it occurs in many European countries. A useful example among the policies reported in the Report Cards is the National Cycling Policy from Sweden, which aims to prioritize cycling in the community and municipalities planning [123].

Profile 2 grouped mostly countries with high prevalence of active transportation, low to medium HDI and higher income inequalities. In most of these countries, access to motorized vehicles is limited, and active travel is happening despite multiple safety concerns [157,158] and the lack of supportive infrastructure [143]. Therefore, for many families, active transportation is likely to reflect necessity rather than choice [159]. Also, many of the countries in this group report important differences between children from rural and urban areas $[117,120,145]$. As suggested by a previous systematic review on active transportation in Africa, these differences could be indicative of the physical activity transition that these countries are experiencing $[157,160]$. In this context, for the countries classified in this profile, preserving active travel while providing improved safety and infrastructure conditions should be a priority. It is important to design strategies to avoid the unintended consequences that economic growth can have on the mode of transport for children and adolescents. A good example of the approaches needed in countries under this profile is the Non-Motorized Transport Policy from Lagos, Nigeria. This policy aims to prioritize active modes of transportation over motorized options, communicating the benefits and importance of active transportation, as well as improving safety conditions for students using active modes to go to school [116].

Profile 3 had more variability in terms of HDI and income inequality, however, the relatively high prevalence of active transportation was a main feature in common between this group of countries. Some of the most successful countries in active transportation are grouped under this profile. However, the conditions in which it is happening are very different. There are countries such as Finland, Denmark, Japan, South Korea and Hong Kong where the use of active modes is supported by the design of compact cities, school siting policies that ensure that children attend to schools located at a walkable distance from home, and supportive infrastructure and regulations [103,104,108,141,155,161]. These factors have made walking and cycling safe options for the daily commuting. Conversely, there are countries like Colombia, Brazil, Mexico, Venezuela and South Africa, where active transportation is prevalent despite safety concerns, the lack of supportive infrastructure and regulations and is likely to be a necessity-driven behaviour [52,60,61,162-165]. Similarly to profile 2 , almost half of the countries in this profile have a relatively high Gini coefficient. However, this profile also includes countries with very low inequality, such as Finland and Denmark. Income inequality has been previously documented as a negative correlate of physical activity and organized sports involvement [14,19]. Notwithstanding, the high prevalence of active transportation in both equal and unequal societies are consistent with literature that suggest that active transportation modes could be an opportunity to bridge the inequities in transportation [18] as well as in other domains of physical activity. Due 
to the diversity of contexts found in this profile, different approaches are needed to promote or maintain active travel. School siting policies that take into account the proximity between schools and children's homes, like those implemented in Japan and Hong Kong [103,104,107], can be useful for growing cities. Also, multi-component strategies, such as the Bike to school program in Colombia are a good reference for countries that aim to provide access, skills, and support to bike to school in safe conditions [110]. Furthermore, Ciclovias or Open Streets programs are a good model for countries where active transportation to school is already prevalent and aim to increase walking and cycling to other destinations in the leisure time [112,166].

Regarding the strategies to improve active transportation, it is concerning to find that major correlates of active transportation such as distance and the perceived convenience of driving are not mentioned among the strategies proposed by the Report Card teams. Future versions of the Report Cards, as tools to communicate evidence to stakeholders, should take these important factors into consideration in order to advocate for active transportation addressing its most important drivers.

Our results can contribute to the call for measures of conditions related to all children wellbeing made by a recent commission sponsored by the WHO, UNICEF and The Lancet. This commission identified that inequities and climate change are undermining children's right to a healthy environment in both, the poorest and wealthiest countries [167]. Given that the transportation sector accounts for almost $25 \%$ of global greenhouse gas emissions [168], local, regional, and national policymakers and practitioners should implement interventions that support children's active transportation in all socioeconomic contexts.

\subsection{Strengths and Limitations of the Study}

Strengths of this study include the availability of active transportation data from 47 countries from all continents, and the harmonized selection of the best available evidence in each country. Our analyses contributed with a diverse context perspective to the emerging evidence on international comparisons of active transportation, which has focused on specific groups of countries in previous studies $[169,170]$. Although most countries reported nationally representative data on active transportation, in some countries, the best available evidence consisted of local data. The main limitations of the study were the diversity in the quality of the data reported, and the broad benchmark proposed for active transportation in the Global Matrix 3.0, which led to variations in the definition of active transportation across countries. The important amount of missing data in the Community and Environment indicator $(26 \%)$ and the heterogeneity of the data reported across countries did not allow to include it as a variable of interest in the LPA, despite its relevance for active transportation. For example, including data on average distances for active transportation by country in future studies could strengthen the model and enrich the profiling of countries as distance is one of the most consistent predictors of active transportation. Also, since we analyzed aggregated data at the country level, a sample size of 47 is small and has limited power for the LPA. This could partly explain the heterogeneity observed in the profiles, mainly in profile 1. Regarding the policies and practices reviewed, there was also heterogeneity in the information reported across countries. Future versions of the Global Matrix can strengthen the guidance on desirable information to report in this regard, such as the inclusion of active transportation to school in National Education Acts or their equivalents in each country. The sample included in this study represents approximately $25 \%$ of the total countries in the world. The inclusion of a larger sample of countries in future studies could provide a clearer picture of profiles according to active transportation and sociodemographic variables.

\section{Conclusions}

This work allowed for a deeper exploration of the active transportation information reported by all the countries participating in the Global Matrix 3.0. Based on our findings, we identified the need to standardize definitions of active transportation to be able to make more meaningful comparisons. The LPA conducted allows for the inference that countries belonging to a specific profile have a 
greater probability of sharing certain characteristics among them compared to the countries belonging to other profiles. Given the variation by geographic region and even HDI, this approach is useful for identification of more meaningful groupings that can facilitate the cross-fertilization of efforts to promote active transportation, and therefore, to "power the movement to get kids moving", as is intended by the Global Matrix initiative [171]. The Active Healthy Kids Global Alliance can contribute to improving active travel surveillance providing guidance to countries involved in future versions of the Global Matrix. A more comprehensive approach to active transportation surveillance that considers duration, distance, frequency, direction, other destinations than school and the contribution of active transportation to school to overall active transportation, could improve the understanding of this behaviour and its potential to increase overall physical activity.

Author Contributions: Conceptualization, S.A.G. and S.A.; methodology, S.A.G. and J.D.B.; software, J.D.B.; formal analysis, S.A.G. and J.D.B.; investigation, S.A.G., S.A., J.D.B. and M.S.T.; resources, M.S.T.; data curation, S.A.G., S.A. and J.D.B.; writing—original draft preparation, S.A.G.; writing—review and editing, S.A., J.D.B., R.L. and M.S.T.; visualization, J.D.B.; supervision, M.S.T.; project administration, S.A.; funding acquisition, M.S.T. All authors have read and agreed to the published version of the manuscript.

Funding: S.A.G. was supported by the Government of Ontario and the University of Ottawa through the Ontario Trillium Scholarship for doctoral studies.

Acknowledgments: The authors would like to acknowledge the then Active Healthy Kids Global Alliance Executive Committee for modifying and standardizing the benchmarks and grading rubric and leading this international initiative. We are grateful for all the hard work by each participating country's Report Card Work Group and Leaders and all other members of their Report Card Committees. We also want to thank Megan Forse for her work compilating the data from the report cards.

Conflicts of Interest: The authors declare no conflict of interest.

\section{References}

1. Sallis, J.F.; Bull, F.; Guthold, R.; Heath, G.W.; Inoue, S.; Kelly, P.; Oyeyemi, A.L.; Perez, L.G.; Richards, J.; Hallal, P.C. Progress in physical activity over the Olympic quadrennium. Lancet 2016, 388, 1325-1336. [CrossRef]

2. Ikeda, E.; Hinckson, E.; Witten, K.; Smith, M. Assessment of direct and indirect associations between children active school travel and environmental, household and child factors using structural equation modelling. Int. J. Behav. Nutr. Phys. Act. 2019, 16, 1-17. [CrossRef] [PubMed]

3. Larouche, R.; Saunders, T.J.; Faulkner, G.E.J.; Colley, R.; Tremblay, M. Associations between active school transport and physical activity, body composition, and cardiovascular fitness: A systematic review of 68 studies. J. Phys. Act. Health 2014, 11, 206-227. [CrossRef]

4. Centers for Disease Control and Prevention (CDC) Transportation Health Impact Assessment Toolkit. Available online: https://www.cdc.gov/healthyplaces/transportation/promote_strategy.htm (accessed on 20 August 2019).

5. Lubans, D.R.; Boreham, C.A.; Kelly, P.; Foster, C.E. The relationship between active travel to school and health-related fitness in children and adolescents: A systematic review. Int. J. Behav. Nutr. Phys. Act. 2011, 8, 5. [CrossRef] [PubMed]

6. Andersen, L.B.; Wedderkopp, N.; Kristensen, P.; Moller, N.C.; Froberg, K.; Cooper, A.R. Cycling to school and cardiovascular risk factors: A longitudinal study. J. Phys. Act. Health 2011, 8, 1025-1033. [CrossRef]

7. Sun, Y.; Liu, Y.; Tao, F.B. Associations between active commuting to school, body fat, and mental well-being: Population-based, cross-sectional study in China. J. Adolesc. Health 2015, 57, 679-685. [CrossRef]

8. Ruiz-Ariza, A.; de la Torre-Cruz, M.J.; Redecillas-Peiró, M.T.; Martínez-López, E.J. Influencia del desplazamiento activo sobre la felicidad, el bienestar, la angustia psicológica y la imagen corporal en adolescentes. Gac. Sanit. 2015, 29, 454-457. [CrossRef]

9. Fusco, C.; Moola, F.; Richichi, V. Toward an understanding of children's perceptions of their transport geographies: (non)active school travel and visual representations of the built environment. J. Transp. Geogr. 2012, 20, 62-70. [CrossRef]

10. Marshall, J.D.; Wilson, R.D.; Meyer, K.L.; Rajangam, S.K.; McDonald, N.C.; Wilson, E.J. Vehicle Emissions during Children's School Commuting: Impacts of Education Policy. Environ. Sci. Technol. 2010, 44, 1537-1543. [CrossRef] 
11. Larouche, R. Last Child Walking?-Prevalence and Trends in Active Transportation. In Children's Active Transportation; Larouche, R., Ed.; Elsevier Inc.: Cambridge, UK, 2018; pp. 53-71. ISBN 978-0-12-811931-0.

12. Larouche, R.; Sarmiento, O.L.; Broyles, S.T.; Denstel, K.D.; Church, T.S.; Barreira, T.V.; Chaput, J.-P.; Fogelholm, M.; Hu, G.; Kuriyan, R.; et al. Are the correlates of active school transport context-specific? Int. J. Obes. Suppl. 2015, 5, S89-S99. [CrossRef]

13. Guthold, R.; Cowan, M.J.; Autenrieth, C.S.; Kann, L.; Riley, L.M. Physical activity and sedentary behavior among schoolchildren: A 34-country comparison. J. Pediatr. 2010, 157, 43-49.e1. [CrossRef] [PubMed]

14. Aubert, S.; Barnes, J.D.; Abdeta, C.; Abi Nader, P.; Adeniyi, A.F.; Aguilar-Farias, N.; Andrade Tenesaca, D.S.; Bhawra, J.; Brazo-Sayavera, J.; Cardon, G.; et al. Global Matrix 3.0 Physical Activity Report Card Grades for Children and Youth: Results and Analysis From 49 Countries. J. Phys. Act. Health 2018, 15, S251-S273. [CrossRef] [PubMed]

15. Aubert, S.; Barnes, J.D.; Forse, M.L.; Turner, E.; González, S.A.; Kalinowski, J.; Katzmarzyk, P.T.; Lee, E.Y.; Ocansey, R.; Reilly, J.J.; et al. The international impact of the active healthy kids global alliance physical activity report cards for children and youth. J. Phys. Act. Health 2019, 16, 679-697. [CrossRef] [PubMed]

16. United Nations Development Programme. Human Development Report 2016 "Human Development for Everyone"; United Nations Development Programme: New York, NY, USA, 2016.

17. The World Bank Gini index (World Bank Estimate). Available online: https://datacatalog.worldbank.org/ gini-index-world-bank-estimate-1 (accessed on 25 December 2019).

18. Lee, R.J.; Sener, I.N.; Jones, S.N. Understanding the role of equity in active transportation planning in the United States. Transp. Rev. 2017, 37, 211-226. [CrossRef]

19. Elgar, F.J.; Pförtner, T.K.; Moor, I.; De Clercq, B.; Stevens, G.W.J.M.; Currie, C. Socioeconomic inequalities in adolescent health 2002-2010: A time-series analysis of 34 countries participating in the Health Behaviour in School-aged Children study. Lancet 2015, 385, 2088-2095. [CrossRef]

20. Stanley, L.; Kellermanns, F.W.; Zellweger, T.M. Latent Profile Analysis: Understanding Family Firm Profiles. Fam. Bus. Rev. 2017, 30, 84-102. [CrossRef]

21. Rosenberg, J.M.; Beymer, P.N.; Anderson, D.J.; Schmidt, J.A. tidyLPA: An R Package to Easily Carry Out Latent Profile Analysis (LPA) Using Open-Source or Commercial Software. J. Open Source Softw. 2018, 3, 978. [CrossRef]

22. World Health Organization Global School-Based Student Health Survey (GSHS). Available online: https: //www.who.int/ncds/surveillance/gshs/en/ (accessed on 15 August 2020).

23. Roberts, C.; Freeman, J.; Samdal, O.; Schnohr, C.W.; de Looze, M.E.; Nic Gabhainn, S.; Iannotti, R.; Rasmussen, M. International HBSC Study Group The Health Behaviour in School-aged Children (HBSC) study: Methodological developments and current tensions. Int. J. Public Health 2009, 54 (Suppl. 2), 140-150. [CrossRef]

24. Nylund, K.L.; Asparouhov, T.; Muthén, B.O. Deciding on the number of classes in latent class analysis and growth mixture modeling: A Monte Carlo simulation study. Struct. Equ. Model. 2007, 14, 535-569. [CrossRef]

25. Sasakawa Sports Foundation. The 2015 SSF National Sports-Life Survey of Children and Young People. Executive Summary; Sasakawa Sports Foundation: Tokyo, Japan, 2015.

26. Paudel, S.; Subedi, N.; Mehata, S. Physical activity level and associated factors among higher secondary school students in banke, Nepal: A cross-sectional study. J. Phys. Act. Health 2016, 13, 168-176. [CrossRef]

27. Makaza, D.; Khumalo, B.; Makoni, P.; Mazulu, M.; Dlamini, K.; Tapera, E.; Banda, M.; Mlalazi, T.; Gundani, P.; Chaibva, C. Nutritional Status and Physical Fitness Profiles, Knowledge, Attitudes, Nutritional and Physical Activity Practices of Zimbabwean Primary School Children: The Zimbabwe Baseline Study. Unpublished manuscript. National University of Science and Technology: Bulawayo, Zimbabwe, 2015.

28. Sithole, E. Global School-Based Health Survey Zimbabwe, Unpublished Report; Harare, Zimbabwe, 2003.

29. Pilgaard, M.; Rask, S. Danskernes Motions- og Sportsvaner. 2016. Available online: https://www.idan.dk/ vidensbank/downloads/danskernes-motions-og-sportsvaner-2016/9a94e44b-4cf5-4fbe-ac89-a696011583d5 (accessed on 15 August 2020).

30. Kokko, S.; Mehtälä, A.; Villberg, J.; Ng, K.; Hämylä, R. The Physical Activity Behaviours of Children and Adolescents in Finland. Results of the LIITU Study; Kokko, S., Mehtäla, A., Eds.; National Sports Council: Helsinki, Finland, 2016.

31. Huang, W.Y.; Wong, S.H.; He, G. Is a change to active travel to school an important source of physical activity for Chinese children? Pediatr. Exerc. Sci. 2017, 29, 161-168. [CrossRef] [PubMed] 
32. Korea Centers for Disease Control and Prevention. The Seventh Korea National Health and Nutrition Examination Survey (KNHANES VII-1). User Guide; Korea Centers for Disease Control and Prevention: Chung-cheonbuk-do, Korea, 2018.

33. Instituto Colombiano del Bienestar Familiar; Instituto Nacional de Salud; Ministerio de la Protección Social. Encuesta Nacional de la Situación Nutricional en Colombia 2015 ENSIN; Instituto Colombiano de Bienestar Familiar: Bogotá, Colombia, 2018.

34. Usman Ahmadu, B.; Maigana Usiju, N.; Ibrahim, A.; Adamu Adiel, A.; Tumba, D.; Rimamchika, M.; Solomon, J.D. Lingering hunger among primary school pupils residing in rural areas of Borno State, North-Eastern Nigeria: Implication for education and food supplementation programs. Glob. Adv. Res. J. Food Sci. Technol. 2012, 1, 093-097.

35. Adeomi, A.A.; Adeoye, O.A.; Bamidele, J.O.; Abodunrin, O.L.; Odu, O.; Adeomi, O.A. Pattern and determinants of the weight status of school-age children from rural and urban communities of Osun state, Nigeria: A comparative study. J. Med. Nutr. Nutraceuticals 2015, 4, 107. [CrossRef]

36. BG Be Active. First Bulgarian Report Card 2018 Active Healthy Kids; BG Be Active: Plovdiv, Bulgaria, 2018.

37. Mohan, A.; Harish, R. Be Activ Chennai Study. Madras Diabetes Research Foundation, Chennai, India. Unpublished Work. 2018.

38. Ghattu, K.; Kalyanaraman, K. Mysuru Study. CSI Holdsworth Memorial Hospital, Mysuru, India. Unpublished Work, 2018.

39. Tetali, S.; Edwards, P.; Roberts, G.V.S.M.I. How do children travel to school in urban India? A cross-sectional study of 5842 children in Hyderabad. BMC Public Health 2016, 16, 1-7. [CrossRef] [PubMed]

40. Dandona, R.; Anil Kumar, G.; Ameratunga, S.; Dandona, L. Road use pattern and risk factors for non-fatal road traffic injuries among children in urban India. Injury 2011, 42, 97-103. [CrossRef] [PubMed]

41. Anitha Rani, M.; Sathiyasekaran, B.W.C. Behavioural determinants for obesity: A cross-sectional study among urban adolescents in India. J. Prev. Med. Public Health 2013, 46, 192-200. [CrossRef]

42. Dutch National Institute for Public Health and the Environment (RIVM) Leefstijlmonitor. Available online: https://www.rivm.nl/leefstijlmonitor (accessed on 15 August 2020).

43. Ministerio de Sanidad Servicios Sociales e Igualdad Estudio ALADINO 2015: Estudio de Vigilancia del Crecimiento, Alimentación, Actividad Física, Desarrollo Infantil y Obesidad en España 2015; Agencia Española de Consumo, Seguridad Alimentaria y Nutrición: Madrid, Spain, 2016.

44. Direcció General de Planificació en Salut; Departament de Salut; Institut d'Estadística de Catalunya Enquesta de Salut de la Població, Estadística Oficial Prevista al Pla estadístic de Catalunya Vigent. Available online: https://salutweb.gencat.cat/ca/el_departament/estadistiques_sanitaries/enquestes/esca/ (accessed on 15 August 2020).

45. Méndez-pérez, B.; Martín-rojo, J.; Castro, V.; Herrera-cuenca, M.; Landaeta-jiménez, M.; Ramírez, G.; Vásquez, M.; Rivas, P.H.; Rosalía, C. Estudio Venezolano de Nutrición y Salud : Perfil antropométrico y patrón de actividad física. Grupo del Estudio Latinoamericano de Nutrición y Salud. The Venezuelan Study of Nutrition and Health : Anthropometric profile and pattern of physical activity. Venez Nutr. 2017, 30, 53-67.

46. Bel, S.; Van den Abeele, S.; Lebacq, T.; Ost, C.; Brocatus, L.; Stiévenart, C.; Teppers, E.; Tafforeau, J.; Cuypers, K. Protocol of the Belgian food consumption survey 2014: Objectives, design and methods. Arch. Public Health 2016, 74, 1-11. [CrossRef]

47. Chen, P. Physical activity, physical fitness, and body mass index in the Chinese child and adolescent populations: An update from the 2016 Physical Activity and Fitness in China-The Youth Study. J. Sport Health Sci. 2017, 6, 381-383. [CrossRef]

48. Pavelka, J.; Sigmundová, D.; Hamřík, Z.; Kalman, M.; Sigmund, E.; Mathisen, F. Trends in Active Commuting to School among Czech Schoolchildren from 2006 to 2014. Cent. Eur. J. Public Health 2017, 25 (Suppl. 1), S21-S25. [CrossRef]

49. Vorlíček, M.; Rubín, L.; Dygrýn, J.; Mitáš, J. Pomáhá aktivní docházka/dojížd'ka českým adolescentům plnit zdravotní doporučení pro pohybovou aktivitu? Tělesná Kult. 2018, 40, 112-116. [CrossRef]

50. Instituto Nacional de Estadística y Geografía-INEGI Encuesta Intercensal. Available online: http://www. inegi.org.mx/est/contenidos/Proyectos/encuestas/hogares/especiales/ei2015/ (accessed on 28 March 2020).

51. Romero-Martínez, M.; Shamah-Levy, T.; Cuevas-Nasu, L.; Gómez-Humarán, I.M.; Gaona-Pineda, E.B.; Gómez-Acosta, L.M.; Rivera-Dommarco, J.Á.; Hernández-ávila, M. Diseño metodológico de la encuesta nacional de salud y nutrición de medio camino 2016. Salud Publica Mex. 2017, 59, 299-305. [CrossRef] [PubMed] 
52. Ferrari, G.L.D.M.; De Victo, E.R.; Ferrari, T.K.; Solé, D. Active transportation to school for children and adolescents from Brazil: A systematic review. Rev. Bras. Cineantropometria Desempenho Hum. 2018, 20, 406-414. [CrossRef]

53. Mazur, J.; Oblacińska, A.; Jodkowska, M. Physical Activity of School Children Aged 9-17; Institute of Mother and Child: Warsaw, Poland, 2013.

54. Wojtyła-Buciora, P.; Bołdowski, T.; Wojtyła, C.; Żukiewicz-Sobczak, W.; Juszczak, K.; Łabędzka-Gardy, M.; Wojtyła, A.; Krauss, H. An all-Poland survey of physical activity and sedentary lifestyles for middle school, high school and university students. J. Health Inequalities 2017, 1, 70-77. [CrossRef]

55. Riley, R.; Mohun, R. Travel to School in Scotland. Hands Up Scotland Survey 2016: National Summary Report; Sustrans: Bristol, England, 2017.

56. Transport Scotland. Transport and Travel in Scotland 2016; National Statistics: Edinburgh, Scotland, 2017.

57. Jurak, G.; Kovač, M.; Starc, G. The ACDSi 2013-the analysis of children's development in slovenia 2013: Study protocol. Anthropol. Noteb. 2013, 19, 123-143.

58. Starc, G.; Kovač, M.; Strel, J.; Pajek, M.B.; Golja, P.; Robič, T.; Kotnik, K.Z.; Grum, D.K.; Filipčič, T.; Sorí, M.; et al. The ACDSi 2014-A decennial study on adolescents' somatic, motor, psychosocial development and healthy lifestyle: Study protocol. Anthropol. Noteb. 2015, 21, 107-123.

59. Statistics South Africa General Household Survey 2013; Statistics South Africa: Pretoria, South Africa, 2015.

60. Simons, A.; Koekemoer, K.; van Niekerk, A.; Govender, R. Parental supervision and discomfort with children walking to school in low-income communities in Cape Town, South Africa. Traffic Inj. Prev. 2018, 19, 391-398. [CrossRef]

61. Koekemoer, K.; Van Gesselleen, M.; Van Niekerk, A.; Govender, R.; Van As, A.B. Child pedestrian safety knowledge, behaviour and road injury in Cape Town, South Africa. Accid. Anal. Prev. 2017, 99, 202-209. [CrossRef]

62. Swedish Transport Administration Children's Routes to School, TRV 2013/54076; Swedish Transport Administration: Borlänge, Sweden, 2015.

63. Amornsriwatanakul, A.; Bull, F.; Rosenberg, M. Thailand Physical Activity Children Survey; Thailand Physical Activity Research Centre and University of Western Australia: Perth, Australia, 2015.

64. World Health Organization Global School-Based Student Health Survey (GSHS)-Datasets. Available online: https://www.who.int/ncds/surveillance/gshs/datasets/en/ (accessed on 15 August 2020).

65. World Health Organization 2014 Global School-based Student Health Survey (GSHS) results: Bangladesh Survey. 2014. Available online: https://www.who.int/ncds/surveillance/gshs/BDH2014_public_use_ codebook.pdf?ua=1 (accessed on 16 August 2020).

66. Department of Transport National Travel Survey: England 2016. Statistical Release. 2016. Available online: https://assets.publishing.service.gov.uk/government/uploads/system/uploads/attachment_data/file/ 633077/national-travel-survey-2016.pdf (accessed on 16 August 2020).

67. NatCen Social Research; University College London. Department of Epidemiology and Public Health Health Survey for England, 2015; UK Data Service: Colchester, England, 2017.

68. Department for Transport Walking and Cycling Statistics, England. 2016. Available online: https://assets.publishing.service.gov.uk/government/uploads/system/uploads/attachment_data/file/ 674503/walking-and-cycling-statistics-england-2016.pdf (accessed on 16 August 2020).

69. Agence Nationale de Sécurité Sanitaire ANSES. Étude Individuelle Nationale des Consommations Alimentaires 3. 2017. Available online: https://www.anses.fr/fr/system/files/NUT2014SA0234Ra.pdf (accessed on 16 August 2020).

70. Équipe de Surveillance et D'épidémiologie Nutritionnelle (Esen) Étude de Santé sur L'environnement, la Biosurveillance, L'activité Physique et la Nutrition (Esteban) 2014-2016; Volet Nutrition, Chapitre Activité Physique et Sédentarité; Santé Publique France: Saint Maurice, Switzerland, 2017.

71. Emeljanovas, A.; Gruodyte-Raciene, R.; Sukys, S.; Mieziene, B.; Rutkauskaite, R.; Trinkuniene, L.; Fatkulina, N.; Gerulskiene, I.; Balsyte, V.; Zabolotnaja, T.; et al. The Lithuanian Physical Activity Report Card for Children and Youth; Lithuanian Sports University: Kaunas, Lithuania, 2018.

72. Wijnhoven, T.M.A.; Van Raaij, J.M.A.; Yngve, A.; Sjöberg, A.; Kunešová, M.; Duleva, V.; Petrauskiene, A.; Rito, A.I.; Breda, J. WHO European childhood obesity surveillance initiative: Health-risk behaviours on nutrition and physical activity in 6-9-year-old schoolchildren. Public Health Nutr. 2015, 18, 3108-3124. [CrossRef] 
73. Meškaitè, A.; Dadelienė, R.; Kowalski, I.M.; Burokienė, S.; Doveikienė, J.; Juocevičius, A.; Raistenskis, J. 11-15 Metu Mokiniu Fizinio Aktyvumo Ir. Sveik. Moksl. 2012, 22, 49-53.

74. Žaltauskè, V. Lietuvos 7-8 metu Vaiku Fizinis Aktyvumas ir jo Sąsajos su Individualiais, Šeimos ir Mokyklos Aplinkos Veiksniais. 2017. Available online: https://193.219.163.160/cris/handle/20.500.12512/95687 (accessed on 16 August 2020).

75. European Comission Special Eurobarometer 472. Report Sport and Physical Activity; European Union. 2018. Available online: https://ec.europa.eu/commfrontoffice/publicopinion/index.cfm/ResultDoc/download/ DocumentKy/82432 (accessed on 16 August 2020).

76. Ministry of Health Annual Update of Key Results 2016/17: New Zealand Health Survey 2017. Available online: https://www.health.govt.nz/publication/annual-update-key-results-2016-17-new-zealand-healthsurvey (accessed on 16 August 2020).

77. Sport New Zealand Active NZ and Active NZ Young People; Sport New Zealand: Wellington, New Zealand, 2018.

78. Health Promotion Agency. 2016 Health and Lifestyles Survey: Methodology Report; Health Promotion Agency: Wellington, New Zealand, 2017.

79. Ministry of Transport. Household Travel Survey; Ministry of Transport: Wellington, New Zealand, 2018.

80. Morton, S.M.B.; Carr, P.E.A.; Bandara, D.K. Growing Up in New Zealand: A Longitudinal Study of New Zealand Children and Their Families; Report 1: Before We Are Born; University of Auckland: Auckland, New Zealand, 2010.

81. Pizarro, A.N.; Santos, M.P.; Ribeiro, J.C.; Mota, J. Physical activity and active transport are predicted by adolescents' different built environment perceptions. J. Public Health 2012, 20, 5-10. [CrossRef]

82. Administração Regional de Saúde do Alentejo (ARSA) Estudo de Saúde da População Infantil da Região Alentejo-Relatório; Núcleo Regional do Alentejo da Plataforma Contra a Obesidade da ARSA: Évora, Portugal, 2012.

83. Ministry of Education. Report of Student Participation in Physical Activity School Year 2015-2016; Sports Administration, Ministry of Education: Taipei City, Taiwan, 2017.

84. Health Promotion Administration. Report of Health Behavior Survey in Junior High School Students 2016; Ministry of Health and Welfare: Taipei City, Taiwan, 2017.

85. Cancer Council Victoria National Secondary Students' Diet and Activity (NaSSDA) survey 2012-2013. Available online: http://www.cancer.org.au/news/media-releases/increase-in-teenagers-screen-use-a-newthreat-to-long-term-health.html (accessed on 6 March 2020).

86. Epidemiology Section ACT Health Year 6 ACT Physical Activity and Nutrition Survey; ACTdata Collection; Epidemiology Section: Canberra, Australia, 2015.

87. Centre for Epidemiology and Evidence NSW Ministry of Health. Child Population Health Survey; Centre for Epidemiology and Evidence: New South Wales, Australia, 2015.

88. Queensland Health. Queensland Child Preventive Health Survey 2018, Report of the Chief Health Officer Queensland; Brisbane, QLD, Australia, 2018.

89. Hardy, L.; Mihrshahi, S.; Drayton, B.; Bauman, A. NSW Schools Physical Activity and Nutrition Survey (SPANS) 2015; Full Report; NSW Department of Health: Sydney, NSW, Australia, 2016.

90. Department of Education and Early Childhood Development. Victorian Child Health and Wellbeing Survey (VCHWS); Department of Education and Early Childhood Development: Victoria, Australia, 2013.

91. Scriven, J.; Morris, S.; Irving, P.; Sheehan, D. Evaluating physical literacy levels of KS1 children in Jersey, Channel Islands Poster. Presented at UKSCA National Conference, Leicester, UK, 4-6 August 2017.

92. Welsh Government National survey for Wales 2016/17 2017. Available online: https://gov.wales/nationalsurvey-wales-april-2016-march-2017 (accessed on 16 August 2020).

93. Hewitt, G.; Anthony, R.; Moore, G.; Melendez-Torres, G.; Murphy, S. Student Health and Wellbeing In Wales: Report of the 2017/18 Health Behaviour in School-aged Children Survey and School Health Research Network Student Health and Wellbeing Survey; Cardiff University: Cardiff, UK, 2019.

94. Research Group of Physical Activity for Health Children's Physical Activity Study 2015 and Schools in Motion Survey 2018; University of Tartu, Institute of Sport Sciences and Physiotherapy: Tartu, Estonia, 2018.

95. States of Guernsey Guernsey Young People's Survey 2016/2017. 2016. Available online: https://www.gov.gg/ ypsurveyarchive (accessed on 18 August 2020).

96. World Health Organization NCDs: Lebanon Global School-Based Student Health Survey (GSHS) Implementation. 2017. Available online: https://www.who.int/ncds/surveillance/gshs/lebanon/en/ (accessed on 16 August 2020). 
97. Canadian Fitness and Lifestyle Research Institute Bulletin 5: Active Transportation Among Children and Youth; Canadian Fitness and Lifestyle Research Institute: Ottawa, ON, Canada, 2018.

98. National Center for Health Statistics. National Health and Nutrition Examination Survey; U.S. Department of Health and Human Services, CDC, National Center for Health Statistics: Hyattsville, MD, USA, 2016.

99. Ministerio de Salud de Chile Encuesta Nacional de Calidad de Vida 2015-2016 (ENCAVI). 2017. Available online: http://www.sochmet.cl/wp-content/uploads/2017/06/Resultados_Abril2017_ENCAVI_201516_Depto_Epidemiolog\%C3\%ADa_MINSAL.pdf (accessed on 16 August 2020).

100. Ministerio de Vivienda y Urbanismo Encuesta de Percepción de Calidad de Vida Urbana (EPCVU 2015). 2016. Available online: http://calidaddevida.colabora.minvu.cl/doc2016/Resultados\%20Encuesta\%20Percepci\% C3\%B3n\%20de\%20Calidad\%20de\%20Vida\%20Urbana\%202015.pdf (accessed on 16 August 2020).

101. García-Hermoso, A.; Saavedra, J.M.; Olloquequi, J.; Ramírez-Vélez, R. Associations between the duration of active commuting to school and academic achievement in rural Chilean adolescents. Environ. Health Prev. Med. 2017, 22, 31. [CrossRef] [PubMed]

102. Rodríguez-Rodríguez, F.; Cristi-Montero, C.; Celis-Morales, C.; Escobar-Gómez, D.; Chillón, P. Impact of distance on mode of active commuting in Chilean children and adolescents. Int. J. Environ. Res. Public Health 2017, 14, 1334. [CrossRef] [PubMed]

103. Mori, N.; Armada, F.; Willcox, D.C. Walking to school in Japan and childhood obesity prevention: New lessons from an old policy. Am. J. Public Health 2012, 102, 2068-2073. [CrossRef] [PubMed]

104. Tanaka, C.; Tanaka, S.; Inoue, S.; Miyachi, M.; Suzuki, K.; Abe, T.; Reilly, J.J. Results from the Japan's 2018 report card on physical activity for children and youth. J. Exerc. Sci. Fit. 2019, 17, 20-25. [CrossRef]

105. Munambah, N.; Matsungo, T.; Makaza, D.; Mahachi, C.; Mlalazi, T.; Masocha, V.; Makoni, P.; Khumalo, B.; Rutsate, S.; Mandaza, D.; et al. Physical Activity and the Nutritional Status of School-Aged Children in Zimbabwe: Current Research Evidence and Policy Implications; Active Health Kids Zimbabwe: Harare, Zimbabwe, 2018.

106. Tammelin, T.; Kämppi, K.; Aalto-Nevalainen, P.; Aira, A.; Halme, N.; Husu, P.; Inkinen, V.; Joensuu, L.; Kokko, S.; Korsberg, M.; et al. Finland's Report Card 2018-Physical Activity for Children and Youth; The LIKES Research Centre for Physical Activity and Health: Jyväskylä, Finland, 2018.

107. Wong, S.H.S.; Huang, W.Y.J.; Sit, C.H.P.; Wong, M.C.S.; Sum, R.K.M.; Wong, S.W.S. The 2018 Active Healthy Kids Hong Kong Report Card on Physical Activity for Children and Youth; The Chinese University of Hong Kong: Hong Kong, China, 2018.

108. Huang, W.Y.; Wong, S.H.S.; Sit, C.H.P.; Wong, M.C.S.; Sum, R.K.W.; Wong, S.W.S.; Yu, J.J. Results from the Hong Kong's 2018 report card on physical activity for children and youth. J. Exerc. Sci. Fit. 2019, 17, 14-19. [CrossRef]

109. Gonzalez, S.A.; Triana, C.A.; Garcia, J.; Sarmiento, O.L. Report Card on Physical Activity of Children and Youth -Colombia 2018-2019; Universidad de los Andes: Bogota, Colombia, 2018.

110. Hidalgo, D.; Miranda, L.; Lleras, N.; Ríos, J. Al Colegio en Bici: Bike-to-School Program in Bogotá, Colombia. Transp. Res. Rec. J. Transp. Res. Board 2016, 2581, 66-70. [CrossRef]

111. Sarmiento, O.; Torres, A.; Jacoby, E.; Pratt, M.; Schmid, T.L.; Stierling, G. The Ciclovía-Recreativa: A MassRecreational Program With Public Health Potential. J. Phys. Act. Health 2010, 7, 163-180. [CrossRef]

112. Triana, C.A.; Sarmiento, O.L.; Bravo-Balado, A.; González, S.A.; Bolívar, M.A.; Lemoine, P.; Meisel, J.D.; Grijalba, C.; Katzmarzyk, P.T. Active streets for children: The case of the Bogotá Ciclovía. PLoS ONE 2019, 14, e0207791. [CrossRef]

113. Congreso de la República de Colombia Ley 1811 de 2016 por la cual se Otorgan Incentivos Para Promover el uso de la Bicicleta en el Territorio Nacional y se Modifica el Código Nacional de Tránsito. 2016. Available online: https://dapre.presidencia.gov.co/normativa/normativa/LEY\%201811\%20DEL\%2021\% 20DE\%20OCTUBRE\%20DE\%202016.pdf (accessed on 16 August 2020).

114. Akinroye, K.K.; Adeniyi, A.F.; Odukoya, O.O.; Adedoyin, R.A.; Odior, S.; Oyeyemi, A.L.; Metseagharun, E.; Fawehinmi, O.S.; Ezeigwe, N.; Ayorinde, R.O. 2018 Nigerian Report Card on Physical Activity for Children and Youth; Nigerian Heart Foundation: Ibadan, Nigeria, 2018.

115. FIA Foundation Walking the Talk: Supporting Nigeria to Adopt Policies for Active Mobility-FIA Foundation. Available online: https://www.fiafoundation.org/blog/2017/november/walking-the-talk-supporting-nigeriato-adopt-policies-for-active-mobility (accessed on 10 February 2020). 
116. Lagos State Ministry of Transportation; Lagos Metropolitan Area Transport Authority; United Nations Environment Programme; Institute for Transportation and Development Policy. Lagos Non-Motorised Transport Policy Empowering Pedestrians and Cyclists for a Better City; Institute for Transportation and Development Policy: Lagos, Nigeria, 2018.

117. Nyawornota, V.K.; Luguterah, A.; Sofo, S.; Aryeetey, R.; Badasu, M.; Nartey, J.; Assasie, E.; Donkor, S.K.; Dougblor, V.; Williams, H.; et al. Results from Ghana's 2018 Report Card on Physical Activity for Children and Youth. J. Phys. Act. Health 2018, 15, S366-S367. [CrossRef]

118. Galaviz, K.; Argumedo García, G.; Gaytán-González, A.; González-Casanova, I.; González Villalobos, M.; Jáuregui, A.; Jáuregui Ulloa, E.; Medina, C.; Pacheco Miranda, Y.; Pérez Rodríguez, M.; et al. Mexican Report Card on Physical Activity of Children and Youth 2018; Universidad de Guadalajara: Guadalajara, Jal, Mexico, 2018.

119. Silva, D.A.S.; Christofaro, D.G.D.; Ferrari, G.L.D.M.; da Silva, K.S.; Nardo, N., Jr.; Silva, R.J.D.S.; Fernandes, R.A.; Barbosa Filho, V.C. Report Card Brazil 2018: It's Time to Take Care of Children and Teenagers! Report on Physical Activity in Brazilian Children and Adolescents; Federal University of Santa Catarina: Florianopolis, Santa Catarina, Brazil, 2018.

120. Abdeta, C.; Teklemariam, Z.; Deksisa, A.; Abera, E. Ethiopia's 2018 Report Card on Physical Activity for Children and Youth; Active Healthy Kids Ethiopia: Harar, Ethiopia, 2018.

121. Active Healthy Kids Scotland. Active Healthy Kids Scotland Report Card 2018; University of Strathclyde: Glasgow, Scotland, 2018.

122. Delisle Nyström, C.; Larsson, C.; Alexandrou, C.; Ehrenblad, B.; Eriksson, U.; Friberg, M.; Hagströmer, M.; Lindroos, A.K.; Nyberg, G.; Löf, M. Active Healthy Kids Sweden 2018; Karolinska Insitutet: Huddinge, Sweden, 2018.

123. Ministry of Enterprise and Innovation. A National Cycling Strategy for More and Safer Cycling; Government Offices of Sweden: Stockholm, Sweden, 2017.

124. Andrade, S.; Ochoa-Aviles, A.; Freire, W.; Romero-Sandoval, N.; Orellana, D.; Contreras, T.; Pillco, J.L.; Sacta, J.; Andrade Muñoz, D.; Ramírez, P.; et al. Results from Ecuador's 2018 Report Card on Physical Activity for Children and Youth. J. Phys. Act. Health 2018, 15, S344-S346. [CrossRef] [PubMed]

125. Aubert, S.; Aucouturier, J.; Vanhelst, J.; Fillon, A.; Genin, P.; Ganière, C.; Praznoczy, C.; Larras, B.; Schipman, J.; Duclos, M.; et al. France's 2018 Report Card on Physical Activity for Children and Youth: Results and International Comparisons. J. Phys. Act. Health 2020, 1-8. [CrossRef] [PubMed]

126. Smith, M.; Ikeda, E.; Hinckson, E.; Duncan, S.; Maddison, R.; Meredith-Jones, K.; Walker, C.; Mandic, S. New Zealand's 2018 Report Card on Physical Activity for Children and Youth; The University of Auckland: Auckland, New Zealand, 2018.

127. Smith, M.; Ikeda, E.; Duncan, S.; Maddison, R.; Hinckson, E.; Meredith-Jones, K.; Walker, C.; Mandic, S. Trends and measurement issues for active transportation in New Zealand's physical activity report cards for children and youth: NZ child/youth active transport trends. J. Transp. Health 2019, 15, 100789. [CrossRef]

128. Chang, C.-K.; Wu, C.-L.; Chen, L.-J.; Fang, S.-H.; Hung, C.-W.; Jiang, R.-S.; Lee, P.-C.; Wang, W.-Y.; Wu, C.-M. The Active Healthy Kids Taiwan Report Card 2018 on Physical Activity for Children and Youth; National Taiwan University of Sport: Taichung, Taiwan, 2018.

129. Active Healthy Kids Australia. Muscular Fitness: It's Time for a Jump Start. The 2018 Active Healthy Kids Australia Report Card on Physical Activity for Children and Young People; Active Healthy Kids Australia: Adelaide, Australia, 2018.

130. Sustrans Active Journeys. Getting Young People Active on the Journey to School; Sustrans: Bristol, England, 2019.

131. Living Streets. Walk to School with Living Streets; Living Streets: London, UK, 2019.

132. Stratton, G.; Edwards, L.; Tyler, R.; Blain, D.; Bryant, A. Active Healthy Kids Wales 2018 Report Card; Active Healthy Kids Wales: Wales, UK, 2018.

133. Williams, A.; Whitman, L.; Page, Y.L.; Page, C.L.; Chester, G.; Sebire, S.J. Results from the Bailiwick of Guernsey's 2018 Report Card on Physical Activity for Children and Youth. J. Phys. Act. Health 2018, 15, S368-S369. [CrossRef] [PubMed]

134. The States of Deliberation of the Island of Guernsey. The On-Island Integrated Transport Strategy-First Periodic Review; Committee for the Environment \& Infrastructure: St. Martin, Guernsey, 2019.

135. Abi Nader, P.; Majed, L.; Sayegh, S.; Hadla, R.; Borgi, C.; Hawa, Z.; Mattar, L.; Fares, E.-J.; Chamieh, M.C.; Habib-Mourad, C.; et al. Results from Lebanon's 2018 Report Card on Physical Activity for Children and Youth. J. Phys. Act. Health 2018, 15. in press. [CrossRef] 
136. Nader, P.A.; Majed, L.; Sayegh, S.; Mattar, L.; Hadla, R.; Chamieh, M.C.; Mourad, C.H.; Fares, E.J.; Hawa, Z.; Bélanger, M. First physical activity report card for children and youth in Lebanon. J. Phys. Act. Health 2019, 16, 385-396. [CrossRef]

137. ParticipACTION. The Brain + Body Equation: Canadian Kids Need Active Bodies to Build Their Best Brains. The 2018 ParticipACTION Report Card on Physical Activity for Children and Youth; ParticipACTION: Toronto, ON, Canada, 2018.

138. Ontario Active School Travel Steps to Success-Ontario Active School Travel. Available online: https: //ontarioactiveschooltravel.ca/steps-to-success-the-5-es/\#fivees\%7C4 (accessed on 14 February 2020).

139. Safe Routes Partnership Safe Routes to School|Safe Routes Partnership. Available online: https://www. saferoutespartnership.org/safe-routes-school (accessed on 15 February 2020).

140. National Physical Activity Plan Alliance. The 2018 United States Report Card on Physical Activity for Children and Youth; National Physical Activity Plan Alliance: Washington, DC, USA, 2018.

141. Aubert, S.; Barnes, J.D.; Aguilar-Farias, N.; Cardon, G.; Chang, C.-K.; Delisle Nyström, C.; Demetriou, Y.; Edwards, L.; Emeljanovas, A.; Gába, A.; et al. Report Card Grades on the Physical Activity of Children and Youth Comparing 30 Very High Human Development Index Countries. J. Phys. Act. Health 2018, 15, S298-S314. [CrossRef]

142. González, S.A.; Barnes, J.D.; Abi Nader, P.; Susana Andrade Tenesaca, D.; Brazo-Sayavera, J.; Galaviz, K.I.; Herrera-Cuenca, M.; Katewongsa, P.; López-Taylor, J.; Liu, Y.; et al. Report Card Grades on the Physical Activity of Children and Youth From 10 Countries With High Human Development Index: Global Matrix 3.0. J. Phys. Act. Health 2018, 15, S284-S297. [CrossRef]

143. Manyanga, T.; Barnes, J.D.; Abdeta, C.; Adeniyi, A.F.; Bhawra, J.; Draper, C.E.; Katapally, T.R.; Khan, A.; Lambert, E.; Makaza, D.; et al. Indicators of Physical Activity Among Children and Youth in 9 Countries With Low to Medium Human Development Indices: A Global Matrix 3.0 Paper. J. Phys. Act. Health 2018, 15, S274-S283. [CrossRef]

144. Whitfield, G.P.; Paul, P.; Wendel, A.M. Active Transportation Surveillance-United States, 1999-2012. MMWR. Surveill. Summ. 2015, 64, 1-17. [CrossRef]

145. Manyanga, T.; Munambah, N.E.; Mahachi, C.B.; Makaza, D.; Mlalazi, T.F.; Masocha, V.; Makoni, P.; Sithole, F.; Khumalo, B.; Rutsate, S.H.; et al. Results from Zimbabwe's 2018 Report Card on Physical Activity for Children and Youth. J. Phys. Act. Health 2018, 15, s433-s435. [CrossRef] [PubMed]

146. Tladi, D.M.; Monnaatsie, M.; Shaibu, S.; Sinombe, G.; Mokone, G.G.; Gabaitiri, L.; Malete, L.; Omphile, H. Results from Botswana's 2018 Report Card on Physical Activity for Children and Youth. J. Phys. Act. Health 2018, 15, s320-s322. [CrossRef] [PubMed]

147. Brazo-Sayavera, J.; Del Campo, C.; Rodríguez, M.J.; da Silva, I.C.M.; Merellano-Navarro, E.; Olivares, P.R. Results from Uruguay's 2018 Report Card on Physical Activity for Children and Youth. J. Phys. Act. Health 2018, 15, s425-s426. [CrossRef] [PubMed]

148. Larouche, R.; Sarmiento, O.L.; Stewart, T. Active Transportation-Is the School Hiding the Forest. In Children's Active Transportation; Elsevier: Amsterdam, The Netherlands, 2018; pp. 243-258.

149. Williams, G.C.; Borghese, M.M.; Janssen, I. Objectively measured active transportation to school and other destinations among 10-13 year olds. Int. J. Behav. Nutr. Phys. Act. 2018, 15. [CrossRef] [PubMed]

150. Herrador-Colmenero, M.; Pérez-García, M.; Ruiz, J.R.; Chillón, P. Assessing modes frequency of commuting to school in youngsters: A systematic review. Pediatr. Exerc. Sci. 2014, 26, 291-341. [CrossRef]

151. Oberski, D. Mixture Models: Latent Profile and Latent Class Analysis. In Modern Statistical Methods for HCI; Robertson, J., Kaptein, M., Eds.; Human-Computer Interaction Series; Springer: Cham, Switzerland, 2016; pp. 275-287.

152. Lee, C.; Zhu, X.; Yoon, J.; Varni, J.W. Beyond distance: Children's school travel mode choice. Ann. Behav. Med. 2013, 45. [CrossRef]

153. McDonald, N.C.; Aalborg, A.E. Why Parents Drive Children to School: Implications for Safe Routes to School Programs. J. Am. Plan. Assoc. 2009, 75, 331-342. [CrossRef]

154. Faulkner, G.E.; Richichi, V.; Buliung, R.N.; Fusco, C.; Moola, F. What's “quickest and easiest?": Parental decision making about school trip mode. Int. J. Behav. Nutr. Phys. Act. 2010, 7, 62. [CrossRef]

155. Pucher, J.; Buehler, R. Making cycling irresistible: Lessons from the Netherlands, Denmark and Germany. Transp. Rev. 2008, 28, 495-528. [CrossRef]

156. Pucher, J.; Dijkstra, L. Making Walking and Cycling Safer: Lessons from Europe. Transp. Q. 2000, 54, 25-50. 
157. Larouche, R.; Oyeyemi, A.L.; Prista, A.; Onywera, V.; Akinroye, K.K.; Tremblay, M.S. A systematic review of active transportation research in Africa and the psychometric properties of measurement tools for children and youth. Int. J. Behav. Nutr. Phys. Act. 2014, 11,1-18. [CrossRef] [PubMed]

158. Oyeyemi, A.L.; Larouche, R. Prevalence and Correlates of Active Transportation in Developing Countries. In Children's Active Transportation; Elsevier: Amsterdam, The Netherlands, 2018; pp. 173-191.

159. Salvo, D.; Reis, R.S.; Sarmiento, O.L.; Pratt, M. Overcoming the challenges of conducting physical activity and built environment research in Latin America: IPEN Latin America. Prev. Med. (Baltim.) 2014, 69, S86-S92. [CrossRef] [PubMed]

160. Katzmarzyk, P.T.; Mason, C. The physical activity transition. J. Phys. Act. Health 2009, 6, 269-280. [CrossRef] [PubMed]

161. Broberg, A.; Sarjala, S. School travel mode choice and the characteristics of the urban built environment: The case of Helsinki, Finland. Transp. Policy 2015, 37, 1-10. [CrossRef]

162. Sarmiento, O.L.; Lemoine, P.; Gonzalez, S.A.; Broyles, S.T.; Denstel, K.D.; Larouche, R.; Onywera, V.; Barreira, T.V.; Chaput, J.-P.; Fogelholm, M.; et al. Relationships between active school transport and adiposity indicators in school-age children from low-, middle- and high-income countries. Int. J. Obes. Suppl. 2015, 5, S107-S114. [CrossRef] [PubMed]

163. Arango, C.M.; Parra, D.C.; Eyler, A.; Sarmiento, O.; Mantilla, S.C.; Gomez, L.F.; Lobelo, F. Walking or bicycling to school and weight status among adolescents from Montería, Colombia. J. Phys. Act. Health 2011, 8 (Suppl. 2), S171-S177. [CrossRef]

164. Herrera-Cuenca, M.; Méndez-Pérez, B.; Landaeta-Jiménez, M.; Marcano, X.; Guilart, E.; Sotillé, L.; Romero, R. Results from Venezuela's 2018 Report Card on Physical Activity for Children and Youth. J. Phys. Act. Health 2018, 15, s427-s429. [CrossRef]

165. Jáuregui, A.; Medina, C.; Salvo, D.; Barquera, S.; Rivera-Dommarco, J.A. Active Commuting to School in Mexican Adolescents: Evidence From the Mexican National Nutrition and Health Survey. J. Phys. Act. Health 2015, 12, 1088-1095. [CrossRef]

166. Torres, A.; Sarmiento, O.L.; Stauber, C.; Zarama, R. The Ciclovia and Cicloruta programs: Promising interventions to promote physical activity and social capital in Bogotá, Colombia. Am. J. Public Health 2013, 103, e23-e30. [CrossRef]

167. Clark, H.; Coll-Seck, A.M.; Banerjee, A.; Peterson, S.; Dalglish, S.L.; Ameratunga, S.; Balabanova, D.; Bhan, M.K.; Bhutta, Z.A.; Borrazzo, J.; et al. A future for the world's children? A WHO-UNICEF-Lancet Commission. Lancet 2020, 395, 605-658. [CrossRef]

168. Sims, R.; Schaeffer, R.; Creutzig, F.; Cruz-Núñez, X.; D’Agosto, M.; Dimitriu, D.; Figueroa Meza, M.J.; Fulton, L.; Kobayashi, S.; Lah, O.; et al. Transport. In Climate Change 2014: Mitigation of Climate Change. Contribution of Working Group III to the Fifth Assessment Report of the Intergovernmental Panel on Climate Change; Edenhofer, O., Pichs-Madruga, R., Sokona, Y., Farahani, E., Kadner, S., Seyboth, K., Adler, A., Baum, I., Brunner, S., Eickemeier, P., et al., Eds.; Cambridge University Press: Cambridge, UK; New York, NY, USA, 2014; pp. 599-670.

169. Peralta, M.; Henriques-Neto, D.; Bordado, J.; Loureiro, N.; Diz, S.; Marques, A. Active Commuting to School and Physical Activity Levels among 11 to 16 Year-Old Adolescents from 63 Low- and Middle-Income Countries. Int. J. Environ. Res. Public Health 2020, 17, 1276. [CrossRef] [PubMed]

170. Aguilar-Farias, N.; Martino-Fuentealba, P.; Carcamo-Oyarzun, J.; Cortínez-O’Ryan, A.; Cristi-Montero, C.; Von Oetinger, A.; Sadarangani, K.P. A regional vision of physical activity, sedentary behaviour and physical education in adolescents from Latin America and the Caribbean: Results from 26 countries. Int. J. Epidemiol. 2018, 47, 976-986. [CrossRef] [PubMed]

171. Tremblay, M.S.; Gray, C.E.; Akinroye, K.; Harrington, D.M.; Katzmarzyk, P.T.; Lambert, E.V.; Liukkonen, J.; Maddison, R.; Ocansey, R.T.; Onywera, V.O.; et al. Physical Activity of Children: A Global Matrix of Grades Comparing 15 Countries. J. Phys. Act. Health 2014, 11, S113-S125. [CrossRef] [PubMed]

(C) 2020 by the authors. Licensee MDPI, Basel, Switzerland. This article is an open access article distributed under the terms and conditions of the Creative Commons Attribution (CC BY) license (http://creativecommons.org/licenses/by/4.0/). 